\title{
A FORÇA DO CARGO: REELEIÇÃO DE CHEFES DO EXECUTIVO SUBNACIONAL NO BRASIL E NO URUGUAI (2000-2016)
}

\author{
The strength of the office: re-election of subnational executive chiefs in Brazil \\ and Uruguay (2000-2016)
}

Alvaro Augusto de Borba Barreto'

\section{Resumo}

0 artigo compara eleições para prefeito nas 26 capitais estaduais brasileiras e para intendentes departamentais uruguaios, no período 2000-2016. Analisa o resultado que candidatos e partidos obtêm nessas eleições, tendo como foco principal aquele alcançado pelo incumbent. Observa os pleitos em que o incumbent não se faz presente, por impossibilidade legal ou por que não se reapresenta, bem como aqueles em que, tendo concorrido, confronta um antecessor e/ou quem jamais foi titular do cargo. O resultado mostra que em ambos os países predomina o incumbent, mas que ele é proporcionalmente mais vitorioso no Brasil do que no Uruguai. A razão para essas diferenças reside na força do titular do cargo no Brasil frente ao partido, o que não se verifica no Uruguai, em que ambos são fortes, mas o partido é mais determinante para a vitória.

Palavras-chave: Reeleição; Brasil; Uruguai; Município; Departamento; Chefe do executivo.

\begin{abstract}
The article compares elections for mayor in the 26 Brazilian state capitals and for Uruguayan departmental, in the 2000-2016 period. It analyzes the results that candidates and parties obtain in these elections, having as main focus the one achieved by the incumbent. Observe those claims in which the incumbent is not present, due to legal impossibility or because he does not appear again, as well as those in which he confronts a predecessor and/or who has never been in office. The result shows that in both countries the incumbent predominates, but that it is more efficient in Brazil than in Uruguay. The reason for these differences lies in the strength of the office holder in Brazil vis-à-vis the party, which is not the case in Uruguay, where both are strong, but the party is more decisive for victory.
\end{abstract}

Keywords: Reelection; Brazil; Uruguay; County; Department; Chief executive.

\section{Introdução}

O artigo promove um estudo comparado das eleições para chefe do executivo subnacional do Brasil e do Uruguai, no período 2000-2016, com

\footnotetext{
1 Doutor em História pela Pontificia Universidade Católica do Rio Grande do Sul. Professor do PPG em Ciência Política da Universidade Federal de Pelotas. Artigo produzido no pós-doutorado em Ciência Política, desenvolvido no Centro de Administração e Políticas Públicas (CAPP), do Instituto Superior de Ciências Sociais e Políticas (ISCSP), da Universidade de Lisboa, sob orientação do prof. Pedro Miguel Moreira da Fonseca. E- mail: albarret.sul@terra.com.br
} 
A força do cargo: reeleição de chefes do executivo subnacional no Brasil e no Uruguai (2000-2016) | Alvaro Augusto de Borba Barreto

vistas a identificar semelhanças e diferenças que o fenômeno manifesta nos dois países e explicar as motivações para tais cenários. Especificamente, analisa as cinco disputas para prefeito nas 26 capitais estaduais brasileiras ${ }^{2}$ e as quatro para os 19 intendentes departamentais uruguaios ${ }^{3}$, ocorridas nesse recorte temporal.

Aborda os resultados que os candidatos obtiveram, tendo como foco aqueles alcançados pelo incumbent, o titular do cargo que busca a reeleição ${ }^{4}$, considerando que a participação dele gera uma competição do tipo plebiscitário, na qual está em julgamento a qualidade e a aceitação da gestão (JONES, 1999). Aprecia o desempenho que o incumbent alcança frente a dois tipos de adversários: um antecessor e quem nunca ocupou em definitivo a mesma função, bem como observa aqueles pleitos em que ele não se faz presente. Por fim, insere a questão do papel desempenhado pelos partidos como elemento explicativo.

O problema que move o artigo é saber como se comporta o fenômeno da reeleição de titulares do poder executivo subnacional no Brasil e no Uruguai e que fatores ajudam a compreender esse comportamento. Baseado na máxima neoinstitucionalista de que as instituições importam, assim como nos resultados indicados por outros estudos de igual temática, esperase que regras muito semelhantes - ou que assumiram similitudes a partir de determinado período - produzam resultados parecidos, ou seja, índices aproximados de reapresentação e de reeleição, independentemente das eventuais diferenças existentes entre os países estudados. Contudo, como a investigação pretende explorar, resultados semelhantes não precisam ser alcançados a partir dos mesmos fatores explicativos ou, ao menos, podem ter motivações institucionais distintas.

\footnotetext{
2 Aracaju (SE), Belém (PA), Belo Horizonte (MG), Boa Vista (RR), Campo Grande (MS), Cuiabá (MT), Curitiba (PR), Florianópolis (SC), Fortaleza (CE), Goiânia (GO), João Pessoa (PB), Macapá (AP), Maceió (AL), Manaus (AM), Natal (RN), Palmas (TO), Porto Alegre (RS), Porto Velho (RO), Recife (PE), Rio Branco (AC), Rio de Janeiro (RJ), Salvador (BA), São Luís (MA), São Paulo (SP), Teresina (PI), Vitória (ES).

3 Artigas, Canelones, Cerro Largo, Colonia, Durazno, Flores, Florida, Lavalleja, Maldonado, Montevideo, Paysandú, Río Negro, Rivera, Rocha, Salto, San José, Soriano, Tacuarembó, Treinta y Tres.

4 Conforme Nohlen (2007, p. 287), é "el derecho de un ciudadano (no de un partido) que ha sido elegido y ha ejercido una función pública con renovación periódica de postular y de ser elegido por una segunda vez o indefinidamente para el mismo cargo (ejecutivo) o mandato (legislativo)". Se se encontra no cargo e busca continuar no próximo período, chama-se reeleição imediata. Se já o ocupou e a ele procura retornar, passado um ou mais períodos, denomina-se reeleição mediada.
} 
A força do cargo: reeleição de chefes do executivo subnacional no Brasil e no Uruguai (2000-2016) | Alvaro Augusto de Borba Barreto

O estudo não ignora as significativas diferenças existentes entre os dois países escolhidos para a análise, seja de história e de geografia, seja de organização política, traços culturais e práticas sociais. No entanto, justamente por conta dessas distinções, optou por selecionar variáveis institucionais comuns (reeleição de cargo executivo unipersonal, eleições subnacionais em calendário autônomo), que operaram no mesmo recorte temporal (2000-2016), com vistas a possibilitar a comparação centrada nos efeitos que elas produziram. E, a partir desses resultados, associados a variáveis institucionais dependentes e inerentes à competição política (partidos e candidatos), produzir explicações para o cenário identificado. Do ponto de vista epistemológico, o impulso para o estudo está sintetizado no comentário de Santos (2012, p. 203):

\begin{abstract}
Por que comparar? Todo comparatista possui uma resposta-padrão para esta interrogação: diante da impossibilidade de recorrer a métodos experimentais que permitam o isolamento de variáveis e a repetição de testes, compara-se como recurso para identificar regularidades, baseando-se no cânone milliano, no método das semelhanças e das diferenças ou na observação de variações concomitantes. Mais do que descrever singularidades, o que talvez defina uma abordagem característica da ciência seja sua tentativa de descobrir regularidades, padrões comuns presentes em fenômenos distintos. A partir disso, procura-se responder como variações em alguns fatores provocam consequências sobre outros.
\end{abstract}

Há muitos estudos que comparam elementos dos sistemas políticos dos dois países, mas são trabalhos que envolvem outros Estados do chamado Cone Sul ou uma grande quantidade de países sul-americanos, latino-americanos ou da terceira onda de democratização, como: Shugart e Carey (1992); Mainwaring e Scully (1995); Mainwaring e Shugart (1997); Coppedge (2000); Mainwaring, Brinks e Pérez-Liñan (2001); Lanzaro (2001, 2014); Mainwaring e Jones (2003); Serna (2004); Pérez-Liñan (2004); Anastasia, Melo e Santos (2004); Mainwaring e Torcal (2005); Oliveira (2006); Moreira (2006); Marenco e Serna (2007); Chasquetti (2008); Santana (2008); Cardarello (2009); Silva (2011); Reis (2013); Suárez-Cao e Freidenberg (2014); Torcal (2015); Kestler, Lucca e Krause (2016). Pesquisas centradas apenas no Brasil e no Uruguai, como a de Moreira (2000) e as duas realizadas por Barreto $(2012,2014)$, não são tão comuns.

Portanto, a presente investigação quer ampliar a quantidade e o escopo dos estudos a respeito dessas duas democracias latino-americanas, 
A força do cargo: reeleição de chefes do executivo subnacional no Brasil e no Uruguai (2000-2016) | Alvaro Augusto de Borba Barreto

bem como expandir o conhecimento sobre o fenômeno da reapresentação e da reeleição de chefes de executivo subnacional.

O texto está organizado em quatro seções. A primeira traz uma breve revisão da literatura sobre o tema da reeleição de cargos executivos. A segunda apresenta informações básicas sobre como se organizam os dois sistemas políticos. A terceira traz a justificativa para o recorte escolhido, expõe as principais decisões metodológicas e o desenho da pesquisa. A quarta seção traz os resultados e discute-os.

\section{Revisão de literatura}

A discussão em torno da reeleição do chefe do executivo pode ser distinguida em dois grandes blocos ${ }^{5}$.

O primeiro traz as principais questões associadas ao tema e alicerça os termos do debate que também está presente, de um modo ou de outro, no segundo bloco. Ele versa sobre os significados institucionais que essa possibilidade produz para o sistema político. Trata-se de uma discussão normativa e axiológica, de caráter permanente, cujas raízes podem ser encontradas em textos clássicos do pensamento político moderno, especialmente no artigo 42 de "O Federalista", escrito por Hamilton (SERRAFERO, 1997, 2010, 2011, 2016; CARDARELLO, 2009; CAREY, 2003; NOHLEN, 2007). Embora a discussão abranja o instituto em si, o foco se dá em torno da reeleição imediata e, mais especificamente, daquela relativa ao sistema de presidencialista, pois as mesmas preocupações não são manifestadas diante no parlamentarismo, forma de governo na qual é possível que o titular permaneça vários mandatos consecutivos no cargo.

O predicado da urgência se agregou à discussão após a onda de mudanças em prol da reeleição imediata nos presidencialismos da América Latina, ocorrida a partir dos anos 1990, como Peru (1993), Argentina (1994) e Brasil (1997), a que se seguiram Colômbia (2004) ${ }^{6}$, Bolivia (2008), Equador (2009) até chegar a Venezuela (2009) e Nicarágua (2011), que implantaram a

\footnotetext{
5 Há intenso e relevante conjunto de pesquisas sobre a reeleição em órgãos legislativos. Contudo, ele não será abordado nessa seção, em razão de especificidades que o distinguem daquelas existentes no Executivo. De igual modo, a ênfase principal vai se dedicar a estudos empíricos sobre Brasil e Uruguai.

6 Ressalva-se que Peru reverteu essa possibilidade em 2000 e hoje proíbe a reeleição imediata, embora a admita medida, enquanto a Colômbia (2015) foi ainda mais restritiva e eliminou qualquer forma de reeleição.
} 
A força do cargo: reeleição de chefes do executivo subnacional no Brasil e no Uruguai (2000-2016) | Alvaro Augusto de Borba Barreto

até então desconhecida reeleição indefinida ${ }^{7}$. Tais inovações foram realizadas por diferentes mecanismos institucionais, como assembleias constituintes, reformas constitucionais ou decisões judiciais (PENFOLD; CORRALES; HERNÁNDEZ, 2014).

Para alguns, a não reeleição se associa à alternância no poder e à limitação temporal vistas como garantias contra os poderes já excepcionais do Presidente e a rigidez do mandato, que tem prazo fixo e não pode ser abreviado senão em situações muito específicas, de difícil e traumática realização em termos políticos e sociais. Penfold, Corrales, Hernández (2014, p. 539) ponderam que a proibição da reeleição imediata também era vista como uma medida de comedimento: diminuía tantos os benefícios de exercer a presidência quanto os custos de perder as eleições, o que estimularia consensos políticos e permitiria às oposições melhores condições para aceitar voluntariamente as regras do jogo constitucional.

Quem argumenta que a proibição é boa também indica que a permissão da reeleição é ruim: amplia os riscos de personalização do poder e de perpetuação no cargo, que a intenção de permanecer no comando condiciona a agenda do governante no primeiro mandato e o estimula a abusar do poder, especialmente durante o processo eleitoral (LINZ, 1991; SARTORI, 1996; NOHLEN, 2007). Um exemplo desses riscos figura no comentário de Thompson (2012, p. 283, tradução do autor):

\begin{abstract}
Por que nos preocupa a reeleição e porque nos deve preocupar? Porque a reeleição, se não está rodeada de garantias, mecanismos que permitem que efetivamente a oposição possa organizar-se, que a oposição tenha uma oportunidade real de triunfar, que haja uma equidade que permite que o resultado seja imprevisivel, pelo menos em teoria, estamos atentando contra o caráter autêntico das eleições.
\end{abstract}

No campo oposto, os que advogam favoravelmente à reeleição centram seus argumentos em torno do fato de o mandato único limitar demasiadamente a capacidade de realização do governo, estimular a descontinuidade na administração pública e desprezar a experiência acumulada pelo chefe do executivo. Na mesma medida, limita a ideia do governo responsável e da accountability, o que atinge tanto a capacidade decisória do eleitor (que ele não tem a possibilidade de punir o mau governante ou de consagrar o bom gestor) quanto a do próprio chefe do

7 Para uma análise específica dessa modalidade, ver: Serrafero (2011). 
A força do cargo: reeleição de chefes do executivo subnacional no Brasil e no Uruguai (2000-2016) | Alvaro Augusto de Borba Barreto

executivo (que não tem a perspectiva das instâncias da prestação e da aprovação de contas como garantia para a continuidade no poder) (SARTORI, 1996; MAINWARING; SHUGART, 1997; GINSBURG; MELTON; ELKINS, 2010-2011).

Como destaca Hamilton em um excerto de "O Federalista", seminal para esse debate:

poucos homens não tenderiam a ter muito menos zelo no desempenho de uma missão se soubessem que as prerrogativas do cargo a ela associados teriam de ser necessariamente abandonadas em determinado momento do que se pudessem alimentar a esperança de obter, por mérito, a própria permanência (HAMILTON, 1993, LXXII, p. 183).

Outra peculiaridade da discussão é o fato de ela ser calcada nos riscos e nas potencialidades associadas à reeleição quase sempre considerados em abstrato, como se fossem independentes dos contextos sociais e politicos em que operam e invariáveis nos resultados que produzem. Assim, essas interpretações são apresentadas sem o cotejo com estudos sistemáticos voltados à identificação e à análise de quais variáveis estão relacionadas a este estatuto. E, como há exemplos capazes de consagrar cada um dos argumentos, torna-se uma discussão inconclusiva, sem a possibilidade de alcançar um consenso, ainda que fundamental para compreender as potencialidades e os riscos dessa instituição.

O segundo bloco procura superar as antinomias que se impõem ao antecedente, razão pela qual opera em outra perspectiva epistemológica. Ele se volta a procedimentos indutivos, a partir dos quais pretende verificar empiricamente os efeitos e as causalidades associadas à reeleição.

Aqueles pesquisadores voltados para os efeitos que a reeleição produz, tomando-a como variável independente, dão especial atenção aos diferentes desenhos institucionais, razão pela qual o esforço inicial é distinguir esses desenhos e demonstrar que há várias reeleições possíveis. Serrafero (2010, p. 12) propõe a seguinte escala: 1) reeleição sem limites (ilimitada); 2) imediata por um período (associada com mediada, ou seja, com possibilidade de retorno após um hiato); 3) imediata e fechada (sem possibilidade de retorno); 4) reeleição mediada; 5) proibição absoluta8.

\footnotetext{
8 Para circunscrever aos países analisados nesse artigo: em escala subnacional, Brasil e Uruguai estão no ponto 2; em se tratando da eleição presidencial, o Brasil permanece no ponto 2 e o Uruguai figura no 4.
} 
A força do cargo: reeleição de chefes do executivo subnacional no Brasil e no Uruguai (2000-2016) | Alvaro Augusto de Borba Barreto

Outras peculiaridades são mais sutis e nem todos os estudos atentam a elas, como a necessidade ou não de o titular afastar-se do cargo para concorrer ${ }^{9}$.

Se os efeitos são relevantes, é preciso, também, identificar outros traços institucionais que tipificam a reeleição e a ele conjugam para produzir determinados resultados, seja na competição política, seja no exercício do poder decorrente do resultado da disputa. Naqueles estudos em que há esta perspectiva neoinstitucionalista, o foco tem recaído sobre a verificação do impacto da fórmula eleitoral (pluralidade ou maioria absoluta) e do tipo de sistema partidário (institucionalizado ou não, com partido predominante ou não) sobre a probabilidade de reeleição (SHUGART; CAREY, 1992; MAINWARING; SHUGART, 1997).

A seguir os ensinamentos clássicos de Duverger (1987), retomados por Cox (1997) por meio da ideia de voto estratégico, pode-se dizer que inicialmente os partidos - e, depois, os eleitores -, são estimulados pela fórmula eleitoral a coordenar suas estratégias de entrada, com vistas a maximizar as oportunidades e alcançar a vitória, pois não há espaço para muitas candidaturas viáveis (duas em fórmulas majoritárias simples e três nas que abrem espaço para realização de $2^{\circ}$ turno). Em um cenário com candidato à reeleição, a tendência é que se afirme ainda mais a tendência de formação de dois blocos viáveis: o do incumbent e o da oposição. E, assim, um desafio que o incumbent e seus aliados não têm, apresenta-se para os partidos originalmente não alinhados com ele: vincular-se à candidatura que busca a reeleição e renunciar à intenção de alcançar a titularidade do cargo; lançar candidato próprio e tentar obter apoio; formar uma aliança com outros partidos de oposição, apoiando outro candidato.

O estudo de Conceição (2015), voltado às eleições municipais brasileiras de 2012, procurou testar essas ideias. Nas eleições de maioria simples, o autor não encontrou o efeito incumbent, pois aquelas disputas com ou sem candidato à reeleição apresentaram índices semelhantes de duas candidaturas relevantes, o que o autor chama de "bicandidaturas" (86

\footnotetext{
9 A título de exemplo: o Brasil não faz essa exigência, enquanto o Uruguai, sim. A permanência no cargo traz vantagem potenciais ao incumbent, as quais tentam ser temperados por meio da imposição de extensas condutas vedadas aos agentes públicos durante o período eleitoral - as quais estão presentes nos art. 73-78 da Lei 9.504/97, a chamada lei das eleições brasileira - o que aumenta os custos de monitoramento, assim como de judicialização do processo eleitoral.
} 
A força do cargo: reeleição de chefes do executivo subnacional no Brasil e no Uruguai (2000-2016) | Alvaro Augusto de Borba Barreto

e $84 \%$, respectivamente) ${ }^{10}$. Porém, naquelas definidas por maioria absoluta, ele confirmou a assertiva de Cox (1997), pois 57\% das eleições com incumbent tiveram dois candidatos relevantes e $34 \%$ naquelas sem a presença dele.

Uma interpretação alternativa e mais sensivel a variações, mas convergente com a de Cox (1997), é apresentada por Jones (1999). Ela argumenta que o impacto da participação do incumbent em uma competição pode ser medido pelo número efetivo de candidatos (NEC), uma aplicação dos princípios e da fórmula do Número Efetivo de Partidos (NEP) às eleições ao executivo. Conforme o autor, por conta das vantagens estratégicas associadas ao incumbent e das reações que provocam nos demais possiveis competidores e no eleitorado, eleições com a presença dele tendem a apresentar NEC menor do que as que não contam com candidato à reeleição imediata. Ao simplesmente indicar o efeito redutor que o incumbent exerce sobre a competição, a proposta se mostra menos rígida e mais sensivel a variações do que a anterior, apesar de não estar tão sustentada em uma explicação teoricamente mais sofisticada e exigente ou justamente por causa de suas características mais empíricas. Afinal, basta verificar a redução para confirmar a assertiva de Jones (1999), o que não é suficiente para a afirmativa de Cox (1997).

Cardarello (1999), em seu estudo que engloba eleições subnacionais de Brasil, Uruguai e Argentina, verificou empiricamente esse efeito redutor sugerido por Jones (1999), medido pela comparação do NEC em eleições nas mesmas unidades, submetidas às mesmas fórmulas eleitorais e que contavam ou não com o incumbent.

A outra vertente, que compartilha as mesmas intenções de obter evidências que confirmem a validade de explicações sobre a reeleição da anterior, distingue-se porque a toma como variável dependente. Portanto, o foco está nas relações causais que propiciam a reapresentação do titular do cargo e, principalmente, aumentam as chances de ele ser vencedor. Essa é a

\footnotetext{
10 Uma possível explicação para isso reside no fato de a maioria dos municípios brasileiros contarem com apenas duas candidaturas nominais, como demonstra Vasquez (2016), o que impede a verificação empírica desse efeito redutor produzido pelo incumbent. A outra limitação é metodológica: o autor calculou os resultados por meio da votação dos candidatos, quando o primeiro efeito do incumbent seria diminuir o número de candidaturas nominais e, depois, se fosse o caso de existirem mais do que dois competidores, concentrar a disputa em torno dele e gerar Número Efetivo de Candidatos em torno de 2,0. Como a primeira exigência se confirma - com ou sem incumbent -, ela automaticamente conduz à segunda e a torna "inverificável".
} 
A força do cargo: reeleição de chefes do executivo subnacional no Brasil e no Uruguai (2000-2016) | Alvaro Augusto de Borba Barreto

linha de investigação que o artigo procura promover, como será explicitado em outras seções.

Tal perspectiva analítica pode ser distinguida em razão do tipo de variáveis independentes ou explicativa selecionadas para serem associadas ao fenômeno da reeleição.

Um conjunto expressivo de estudos tem sido realizado nas áreas da Economia, Administração e Ciências Contábeis. Ele segue o pressuposto segundo o qual resultados políticos são dependentes da reputação junto aos eleitores e de indicadores daquilo que a teoria avalia como performance econômica desejável ou pela manipulação de variáveis de curto prazo de parte do governante para obter retorno nas urnas.

Alguns trabalhos internacionais são referência, como os de Nordhaus (1975), Roghoff e Sibert (1988) e Downs (1999), pois fornecem os fundamentos interpretativos a serem testados empiricamente. Mais recentemente, por conta da amplitude e as possibilidades de comparação que gera, ganhou relevância a investigação de Brender e Drazen (2003), que estuda o efeito da gestão fiscal sobre as possibilidades de reeleição dos chefes do Poder Executivo em 74 países, ao longo do período 1960-2003.

Nos estudos nacionais, foram testadas e verificadas como variáveis que, de modo isolado ou combinado, contribuem para a reeleição: promoção de ajuste fiscal, redução do déficit público, responsabilidade na gestão orçamentária. De igual forma, a ampliação das transferências correntes recebidas, dos gastos em infraestrutura e em bens de capital, em politicas sociais ao longo do mandato e/ou no período próximo às eleições (MENEGUIN; BUGARIN, 2001; MENDES; ROCHA, 2004, 2004a; MENEGUIN; BUGARIN; CARVALHO, 2005; ARAÚJO JÚNIOR; CANÇADO; SHIKIDA, 2005; COSTA, 2006; NAKAGUMA; BENDER, 2006; SAKURAI, 2007; SAKURAI; MENEZES FILHO, 2008; UMENO; BUGARIN, 2008; KLEIN, 2010; MELONI, 2011; MENEZES; SAIANI; ZOGHBI, 2011; SILVA; FARONI; BARBIÉRI, 2011; KLEIN; SAKURAI, 2015; CAVALCANTI, 2015, 2016; DIAS; NOSSA; MONTEMOR, 2018; MARCINIUK; BUGARIN, 2019; LAUTENSCHLAGE, 2019).

Outros estudos abordam áreas específicas, atestando o vínculo entre reeleição e mais gastos orçamentários com pessoal (SCARANO, 2018), utilização de programas de transferência de renda, como o Bolsa Família 
A força do cargo: reeleição de chefes do executivo subnacional no Brasil e no Uruguai (2000-2016) | Alvaro Augusto de Borba Barreto

(SHIKIDA et al., 2009), mais dispêndio em saúde (NOVAES, 2007; NOVAES; MATTOS, 2010), melhora no desempenho do município no Índice de Desenvolvimento da Educação Básica (IDEB), tomada como indicador de qualidade da educação e utilização de recursos orçamentários em educação (FIRPO; PIERI; SOUZA, 2017; LIMA, 2018) ou, ainda, investimentos tanto em saúde quanto em educação (CASTELAR; MONTEIRO; JORGE NETO, 2020).

Ao inverso, condenação pelo Tribunal de Contas impacta negativamente nas chances de sucesso de ex-prefeitos, mas não produz efeito tão intenso se se tratar de um incumbent (OLIVEIRA, 2017). Há estudo, como o de Ribeiro Filho (2011), que constata o efeito da possibilidade de ser incumbent sobre a receita tributária e a execução orçamentária, sem considerar, contudo, a efetivação dessa condição e o resultado alcançado.

Esses estudos abrangeram amostras robustas do conjunto dos municipios brasileiros ou recortes que compreendem os municipios de determinada região (Norte, como em SILVA; FARONI; BARBIERI, 2011) ou de unidades da federação brasileira, como Ceará (LIMA, 2018; SCARANO, 2018;), Espírito Santo (DIAS; NOSSA, MONTE-MOR, 2018), Minas Gerais (ARAÚJO JÚNIOR; CANÇADO; SHIKIDA, 2005) e Santa Catarina (LAUTENSCHLAGE, 2019). No entanto, em muitos casos, em razão do período em que foram produzidas, abrangem uma eleição ou pares de eleições, sendo menos comuns estudos longitudinais, que abordem uma série histórica mais longa e produzam resultados mais consolidados.

Um traço característico desses estudos é a tendência de retirarem a competição das estimativas, de modo que o incumbent parece concorrer sem concorrentes, razão pela qual apreciam a reapresentação e o resultado da tentativa de reeleição como produto de um teste sobre o desempenho do governante em diferentes indicadores econômicos, que é realizado por um eleitor que também é essencialmente um calculador guiado pela economia. Em outros termos, são análises em que são negligenciados, quando não esquecidos, os elementos propriamente políticos - como as regras decisórias, partidos e alianças entre eles, perfil e carreiras dos concorrentes etc.

São precisamente esses os elementos que as investigações vinculadas ao campo acadêmico da política incorporam à análise como variáveis 
A força do cargo: reeleição de chefes do executivo subnacional no Brasil e no Uruguai (2000-2016) | Alvaro Augusto de Borba Barreto

explicativas para o cenário em que se processa a disputa e o resultado alcançado pelo incumbent.

O ponto de partida segue um pressuposto afirmado pela literatura internacionais: se o incumbent participa da disputa, ela assume características específicas, nas quais preponderam o voto retrospectivo, efetivos mecanismos de accountability vertical e avaliação reputacional, conforme a orientação teórica adotada (FIORINA, 1981; FEREJOHN, 1986; O'DONNELL, 1998; JONES, 1999; MANIN; PRZEWORSKI; STOKES, 2006).

Todas convergem para afirmar que, nesses casos, o eleitor afiança um novo mandato se avaliar positivamente o governo vigente. Logo, ainda que enfrente opositores respeitados ou antecessores bem-sucedidos, ele possui vantagem estratégica na disputa: tem mais facilidade para obter recursos de financiamento, apoio político, possui resultados a mostrar, já é conhecido, ocupa recorrentemente espaço na mídia e, ainda, pode se utilizar dos recursos do próprio governo para fazer propaganda eleitoral, o que é considerado ilegal e elimina a paridade da disputa (SERRAFERO, 2016).

Além disso, como o eleitor não se mostra engajado politicamente, opera em cenários de racionalidade restrita e apresenta horizonte temporal restrito, por isso valoriza mais o período que está vivenciando, projeta o futuro a partir do modo como sente o presente e tende a moldar suas escolhas em torno do modo como aprecia o governante. Logo, se é bem avaliado, não perde; se for mal avaliado, corre grande risco de ser derrotado, a depender de quem são os adversários; e em condições de igualdade com os demais competidores, tende a ser beneficiado pela condição ostentada e garantir a vantagem.

Dados empíricos confirmam a vantagem do incumbent $71 \%$ dos presidentes norte-americanos que podiam, foram reeleitos, na América Latina a taxa de sucesso alcança 90\% (PENFOLD; CORRALES; HERNÁNDEZ, 2014) ${ }^{11}$, tendência que o artigo corrobora, como será demonstrado a seguir.

Contudo, a questão-chave para essas investigações é identificar as variáveis que configuram a boa avaliação do incumbent, efetivam a vantagem

11 Os autores consideraram 137 eleições presidenciais, em 18 países latino-americanos, em um recorte temporal que vai de 1952 a 2012. 
A força do cargo: reeleição de chefes do executivo subnacional no Brasil e no Uruguai (2000-2016) | Alvaro Augusto de Borba Barreto

estratégica de estar no governo e se convertem em reeleição. Como já foi ponderado, se o desafio e o pressuposto explicativo são o mesmo do conjunto de pesquisas anterior, elas se distinguem porque as variáveis elencadas não são exclusivamente econômicas.

No Brasil, como a reeleição imediata do executivo foi introduzida há relativamente pouco tempo, figuram menos estudos $\mathrm{e}$ as linhas de investigação ainda estão sendo construídas. Pereira e Rennó (2001, 2007) não abordaram especificamente este tipo de pleito, mas mostraram que o advento da reeleição dos chefes do executivo modificou as estruturas de oportunidades de carreira dos políticos e as estratégias dos partidos, refletindo-se também nos índices de permanência e de renovação do legislativo.

Outros trabalhos confirmaram a vantagem do incumbent na disputa eleitoral. Incluem-se nesse grupo: Cardarello (2009), que comparou o resultado obtido pelos chefes dos executivos subnacionais da Argentina, do Brasil e do Uruguai - governadores nos dois primeiros países e intendentes no terceiro - que buscaram a reeleição no período 1982-2007; Barreto (2009), que investigou os prefeitos de 62 municipios (capitais estaduais e aqueles que desde 2000 tinham mais de 200 mil eleitores), no período 19962008; Deliberador e Komata (2010), que analisam a taxa de reeleição em 15 municípios da região Oeste da Grande São Paulo e nas capitais estaduais na eleição de 2008, e a relacionam com o IDH.

Outros autores buscam responder sobre o fator incumbent por meio da análise de regressão descontínua aplicada aos ciclos eleitorais do período 1996-2008. Este é o caso de: Brambor e Ceneviva (2011, 2012), Magalhães (2012) e Moreira (2012). A primeira pesquisa adota dois procedimentos de investigação: avalia agregadamente os desempenhos eleitorais dos incumbents em comparação ao dos desafiantes no período; e considera pares de candidatos que se enfrentam em eleições consecutivas. Ao contrário das pesquisas precedentes, os resultados indicam que

os prefeitos que concorriam à reeleição nesse período experimentaram uma considerável desvantagem eleitoral. Essa desvantagem eleitoral se expressa tanto no efeito negativo da incumbência sobre o desempenho eleitoral dos prefeitos como na baixa proporção de prefeitos que são bem-sucedidos em se reeleger quando concorrem no exercício do cargo (BRAMBOR; CENEVIVA, 2012, p. 18). 
A força do cargo: reeleição de chefes do executivo subnacional no Brasil e no Uruguai (2000-2016) | Alvaro Augusto de Borba Barreto

Os estudos de Magalhães (2012) e de Moreira (2012), ao desagregarem os resultados por eleição, matizam essa conclusão. Para ambos, o incumbent teve desvantagem eleitoral em 2000 e em 2004, mas o cenário se reverteu em 2008.

A segunda tendência presente em investigações da Ciência Política indica que ainda são poucos os estudos que adotam ou incluem o partido como unidade de análise. Titiunik (2011) é um dos pioneiros nesse campo: ele também se utiliza da regressão descontínua como ferramenta de investigação, aplica-a a um par de eleições (2000-2004) e analisa três legendas (PMDB, PSDB e PFL). Contudo, a investigação tem sido criticada por restringir-se a uma observação e a poucos partidos em um universo amplamente multipartidário como o brasileiro, aliada à troca do PSDB pelo PT na presidência que ocorreu entre os dois pleitos analisados (BRAMBOR; CENEVIVA, 2012; MAGALHÃES, 2012; MOREIRA, 2012). Apesar disso, os resultados corroboram os achados dos autores citados: ter o incumbent não é um fator que ajuda os partidos a conseguir a reeleição.

Outro trabalho a citar é o de Barreto (2014). O autor comparou os processos eleitorais brasileiros de 1996-2012 em 62 municipios brasileiros (os mesmos do estudo de 2009) com os dos intendentes uruguaios de 19942010, questionando o papel desempenhado pelo incumbent para a reeleição dos partidos. Os resultados apontam para um cenário distinto daquele construído por Titiunik, ressalvadas as diferenças de recorte temporal e de municipios analisados: quando os partidos brasileiros contam com o incumbent obtêm muito mais sucesso, o que contrasta com o caso uruguaio, no qual os partidos mostram taxas de reeleição mais altas quando não possuem o incumbent.

Um terceiro trabalho é o já citado de Moreira (2012), que incluiu o partido na análise de regressão descontínua, o que lhe permite observar tendências semelhantes àquelas verificadas no caso do incumbent: os coeficientes para as eleições de 2000 e de 2004:

demonstram que se o partido concorre com o prefeito candidato à reeleição ou não, a desvantagem é inalterada. Os resultados negativos de concorrer à reeleição para 2008 sugerem que não era vantajoso apresentar um candidato diferente. Partidos que o fizeram não foram capazes de se beneficiar da 'neutralização' da particular desvantagem da presença do incumbent nas eleições de 2008. Por 
A força do cargo: reeleição de chefes do executivo subnacional no Brasil e no Uruguai (2000-2016) | Alvaro Augusto de Borba Barreto

outro lado, partidos que apoiaram o prefeito em exercício, não foram punidos (MOREIRA, 2012, p. 29, tradução do autor).

Borba e Cervi (2017) procuraram testar o efeito conjunto de diferentes variáveis (recursos de campanha, tempo no Horário Gratuito de Propaganda Eleitoral, reputação do governo, a condição dos candidatos, em especial se ele é o eleito que busca a reeleição), nas eleições para governador e prefeito das capitais estaduais entre 2002 e 2014. Os resultados corroboram a relevância do incumbent, que têm o melhor desempenho, mas também indica que variáveis distintas operam diferentemente conforme o tipo de candidato, sendo que a avaliação de governo é a variável preditiva mais forte para candidatos à reeleição e o tempo no HGPE aparece como a variável que explica melhor o desempenho de opositores.

Machado (2009) focou nas narrativas adotadas no HGPE pelas candidaturas vitoriosas dos incumbents FHC e Lula, respectivamente nas eleições presidenciais de 1998 e de 2006, e nas representações que procuraram construir. O resultado indicou a convergência entre as duas narrativas, que estiveram centradas na relevância da continuidade de seus governos e de suas respectivas agendas, apontadas como bem-sucedidas. De igual forma, elas foram centradas no próprio candidato, exaltando a competência e o carisma deles para o exercício do poder. Além de permitirem a ambos se diferenciar de todos os demais competidores, tais representação apelavam ao caráter plebiscitário e enfatizavam o voto retrospectivo.

Hott (2018) procurou verificar o impacto da migração partidária sobre a reapresentação e a reeleição dos prefeitos nos pleitos de 2004-2012, observando que a troca amplia as chances de reapresentação e que há a tendência de ela obedecer a um timing e uma direção predominantes específicas - após a eleições estadual-nacional e para a base do governador, as quais também aumentam as possibilidades de sucesso eleitoral.

Como se observa, em geral, as investigações listadas acima confirmam a vantagem do incumbent, associando-a a variáveis de ordem econômica ou mais intimamente ligadas às características da própria competição política. $\mathrm{O}$ caminho que o artigo se propõe a perseguir é esse: seguir essa trilha e identificar elementos inerentes à disputa da qual participa o incumbent que influenciam e explicam os resultados por ele alcançados e ajudam a compreender como esse fenômeno se manifesta. A peculiaridade é o fato de o 
A força do cargo: reeleição de chefes do executivo subnacional no Brasil e no Uruguai (2000-2016) | Alvaro Augusto de Borba Barreto

realizar por meio da comparação da escala subnacional de dois países que vivenciaram mudanças recentes nas regras da disputa que os tornaram um pouco mais próximos em seus desenhos institucionais.

\section{Caracterização dos sistemas políticos}

Brasil e Uruguai são dois países sul-americanos que, embora fronteiriços, possuem significativas diferenças. O primeiro se expressa em português e possui população estimada em mais de 210 milhões de pessoas. O segundo apresenta colonização espanhola e não chega a ter 3,5 milhões de habitantes, das quais aproximadamente 54\% concentradas na região metropolitana da capital Montevidéu (BRASIL. IBGE, 2019; URUGUAY. INE, 2017; MEDINA, 2017).

Se a população brasileira é 60 vezes superior, em termos territoriais a relação atinge cerca de 50 vezes, pois o Uruguai é o segundo menor em extensão da América do Sul. Contudo, os indicadores sociais do pequeno país são melhores: a renda per capita é de 16.332 dólares e o IDH 0,795 frente a 10.304 e 0,754 do vizinho (BRASIL. IBGE, 2019; URUGUAY. INE, 2017).

Apesar dessas diferenças, do ponto de vista do arranjo políticoinstitucional há uma série de aproximações que podem ser exaltadas e tornam viável a comparação proposta. Ambos possuem três níveis de administração pública (federal/nacional, estadual/departamental e municipal), cujos titulares dos poderes executivo e legislativo têm caráter eletivo; adotam forma de governo presidencialista, com exigência da obtenção de maioria absoluta dos votos para alcançar o cargo e a consequente possibilidade de realização de ballotage $^{12}$, bem como têm parlamento bicameral. Outras semelhanças é não admitirem candidaturas independentes, permitirem reeleições indefinidas para todos os órgãos pluripessoais e fixarem voto obrigatório nas disputas que outorgam mandato.

As duas personagens analisadas possuem muitas características comuns. São autoridades unipessoais que chefiam o executivo subnacional,

\footnotetext{
12 A diferença é que, no Brasil, a maioria absoluta considera votos válidos, excluindo brancos e nulos, enquanto no Uruguai ela é calculada sobre os votos emitidos, o que torna mais dificil vencer a eleição no $1^{\circ}$ turno. Outra distinção relevante é que o primeiro admite reeleição presidencial imediata e o segundo, veda-a.
} 
A força do cargo: reeleição de chefes do executivo subnacional no Brasil e no Uruguai (2000-2016) | Alvaro Augusto de Borba Barreto

sendo que o intendente atua no departamento uruguaio, correspondente ao segundo nível de administração, e o prefeito, no município, terceiro e último nivel da federação brasileira. Ambos são escolhidos exclusivamente pelos eleitores alistados no respectivo distrito eleitoral e podem concorrer à reeleição imediata e mediada ${ }^{13}$. Outro ponto em comum é que, em seus respectivos países, são escolhidos em pleitos concomitantes e exercem mandato pelo mesmo período (cinco anos no caso uruguaio; quatro, no brasileiro). De igual forma, convivem com órgãos legislativos unicamerais, escolhidos concomitantemente, mas de modo separado ${ }^{14}$.

Também há diferenças a serem destacadas. Apesar de ambos os países terem três níveis de organização do Estado, as estruturas são diferentes, a começar pelo caráter federativo do Brasil e Unitário do Uruguai, o que faz com que essas autoridades brasileiras tenham espaços de atuação mais amplos ${ }^{15}$. O intendente é eleito por maioria simples. A maioria dos prefeitos também o é, mas aqueles de municípios com mais de 200 mil eleitores são escolhidos por maioria absoluta dos votos válidos, a exemplo do que ocorre com o Presidente da República e os governadores dos 26 estados e do Distrito Federal ${ }^{16}$. Tal exigência abre a possibilidade de realização de dois turnos de votação.

O fundamento para adotar prefeitos e intendentes como objeto de pesquisa decorre do fato de se considerar semelhantes os tipos de atividade administrativa por eles exercida e o papel político que desempenham no sistema de cada um dos seus países. Ainda assim, cabe ponderar porque a opção não é comparar prefeitos e alcaides, autoridades que atuam nos

\footnotetext{
13 Os requisitos para ser intendente, são: naturalidade uruguaia ou naturalização há sete anos e ter 30 anos, além de ser nativo do departamento que pretende governar ou nele residir há três anos. Já o prefeito precisa ser brasileiro nato ou naturalizado, ter 21 anos e domicílio eleitoral no distrito correspondente.

14 No Uruguai, trata-se da Junta Departamental, sempre composta por 31 membros, chamados edis departamentais. Eles são eleitos pelo sistema proporcional (fórmula D’Hondt), mas há uma peculiaridade: ao partido do intendente eleito é garantida a maioria de 16 cadeiras (chamada maioria automática), caso não a tenha alcançado pelas urnas; cumprida a regra, as restantes são distribuídas pelo sistema proporcional. Enfim, na prática e se necessário, a fórmula é primeiro majoritária e só em um segundo momento se torna proporcional. Mais detalhes, ver: Moraes (1997-1998). O voto é em lista fechada, hierarquizada e bloqueada. No Brasil, o corpo legislativo se chama Câmara Municipal, sendo seus membros conhecidos como vereadores. A composição varia conforme o contingente populacional da localidade, tendo mínimo de nove e máximo de 55 vagas. Os vereadores são definidos pelo mesmo sistema proporcional que rege os equivalentes nacionais e estaduais: é utilizada a cota Hare (quociente eleitoral) para a primeira distribuição e fórmula D’Hondt para distinguir as cadeiras que sobram. O voto é preferencial.

15 Para mais detalhes sobre os municipios, ver: Neves (2000). Para os departamentos, sugere-se: Gutiérrez (2004).

16 Nas eleições de 2016 havia 92 municipios nessa condição. Dentre as capitais estaduais, atualmente, apenas Palmas (TO) não alcança esse contingente de eleitores.
} 
A força do cargo: reeleição de chefes do executivo subnacional no Brasil e no Uruguai (2000-2016) | Alvaro Augusto de Borba Barreto

municípios desses dois países. Ou, ainda, governadores e intendentes, o que também seria possível, já que o departamento não corresponde plenamente aos estados e nem aos municípios brasileiros e a autoridade brasileira também é unipersonal.

A primeira alternativa é descartada porque, apesar da denominação comum e de corresponderam ao terceiro nível da administração pública, são duas organizações políticas muito distintas entre si. A principal diferença reside no fato de os municípios (ou conselhos municipais) uruguaios serem uma instituição recentes e em processo de implantação ${ }^{17}$, cujas autoridades políticas formam um corpo coletivo, composto por cinco pessoas (Alcaide e quatro conselheiros), o que não ocorre no Brasil, em que há a separação entre Prefeito (chefe do Executivo) e vereadores (membros do legislativo local unicameral). Assim, o município uruguaio é uma autoridade coletiva, liderada pelo Alcaide, enquanto o brasileiro é dirigido por uma autoridade unipersonal, o prefeito, peculiaridade que altera, para além do processo de governo, a própria dinâmica da disputa eleitoral que define os titulares dos respectivos cargos.

Outras das mais sensíveis diferenças estão no grau de competência e de autonomia dessas autoridades municipais: no Brasil, ela é muito mais ampla, o município é ente da federação e tem orçamento e recursos próprios, possui corpo funcional, pode desenvolver políticas públicas e formular legislação próprias em determinadas áreas. De igual forma, o prefeito brasileiro pouco se parece com o Alcaide uruguaio, sendo mais próximo ao Intendente daquele país e também ao governador brasileiro.

No que tange à escolha por comparar o intendente com o prefeito $\mathrm{e}$ não com o governador, ela é mais resultado da escolha do pesquisador, pois não há nenhum impedimento para promover a outra comparação - como o fez, aliás, Cardarello (2009). No entanto, a opção escolhida é derivada de algumas percepções e peculiaridades listadas abaixo, que fazem com que o pesquisador a considere possível, válida e proveitosa.

$\mathrm{Na}$ visão de Cardarello (2009, p. 154), a nível internacional, os departamentos seriam governos equivalentes a províncias ou a estados pela

17 Em 2010, foram criados os primeiros 89 municípios e em 2015, outros 23, totalizando 112 já instalados. Mais informações, ver: Barreto (2015). 
A força do cargo: reeleição de chefes do executivo subnacional no Brasil e no Uruguai (2000-2016) | Alvaro Augusto de Borba Barreto

extensão, população abrangida e por terem vários centros povoados em seu território. O autor tem razão: eles são unidades politico-administrativas que englobam ampla extensão territorial, sendo formados por uma capital, sede do poder local, e diversas cidades, vilas e povoados - sendo que estes, atualmente, podem estar organizados sob a forma de municipio -, o que aparentemente o torna parecido com o estado brasileiro, que tem as mesmas características.

Ainda, os intendentes são autoridades que, no conjunto, abrangem a totalidade do território do país, a exemplo do que ocorre com os governadores. Na mesma perspectiva, Bottinelli (10 marzo 2000) anota que "los municipios propiamente dichos, entendidos en el sentido más estricto del término, como gobiernos de la ciudad, del pueblo y de la localidad, han desaparecido en Uruguay desde la primera administración local que existió que fueron los cabildos"18, permanecendo a figura do departamento, entendido como o governo no qual convivem diferentes localidades.

Porém, a falta de um governo propriamente municipal até 2010 faz com que as esferas local-provincial se confundam no Uruguai - a própria Constituição e a linguagem corrente, inclusive a utilizada pelos acadêmicos, adotam os termos departamental e municipal como intercambiáveis. Do mesmo modo, os intendentes atuam prioritariamente no campo local e têm limitada capacidade de atuação na proposição e na formulação de politicas públicas nacionais, papel este reservado à Presidência da República e, em menor escala, ao poder legislativo nacional ${ }^{19}$. Consequentemente, a gestão pública dos departamentos envolve uma complexidade e oferece recursos políticos semelhantes aos dos municípios brasileiros, muito em razão do restrito contingente populacional envolvido em cada um e da autonomia que possuem os departamentos em uma estrutura de Estado Unitário.

\footnotetext{
18 O texto foi escrito antes da criação dos municipios no país.

19 Ainda assim, análises como as de Guerrini (2000), Eaton (2004, p. 193-198), Cardarello e Guerrini (2004), Salvat (2006, p. 11-12) e Cardarello (2009, p. 164-167) apontam a transformação que o papel do intendente vivenciou desde a redemocratização do país, nos anos 1980. Eles passaram da condição de referências locais a figuras de destaque em seus partidos, seja pela mudança do modelo tradicional de Estado keynesiano, seja pela ampliação da relevância dos departamentos em razão da ampliação das políticas de descentralização. Esta mudança é sintetizada pela metáfora de Laurnaga e Guerrini (1994), segundo a qual eles passaram de bom vizinho a empreendedores. Contribuiu para este processo a constitucionalização do Congresso de Intendentes, ocorrida na reforma constitucional de 1997, que é um órgão colegiado, responsável pela coordenação das políticas dos governos subnacionais e a celebração de convênios com o poder central.
} 
A força do cargo: reeleição de chefes do executivo subnacional no Brasil e no Uruguai (2000-2016) | Alvaro Augusto de Borba Barreto

Pode-se ilustrar a situação com referências à escala populacional. Com exceção dos departamentos de Montevidéu, Canelones e Maldonado, nenhum outro possui mais de 150 mil habitantes, enquanto as 27 unidades da federação brasileira ultrapassam essa marca e há 194 municípios que, sozinhos, também a superam (BRASIL. IBGE, 2019). Além disso, o Uruguai possui como peculiaridade a macrocefalia da capital Montevidéu, que, embora seja o departamento com a menor área dentre todos, responde por cerca de $40 \%$ da população. Esse contingente ascende a $54 \%$ se for incluída a área metropolitana, que abrange parte de Canelones e de San José, mas correspondente a $1 \%$ do território nacional (MEDINA, 2017, p. 67). A densidade demográfica da capital é de 2.640 habitantes $/ \mathrm{km}^{2}$ e a do país atinge 19,9 (URUGUAI, INE, 2017).

Seguindo a perspectiva adotada pelo artigo, Buquet, Chasquetti e Moraes (1998, p. 9) afirmam que o intendente é uma autoridade executiva local, cujos poderes, atribuições e funções são mais parecidas com as de um prefeito do que de um governador. Cardarello (2009, p. 154), que optou em seu estudo por compará-lo com os governadores do Brasil e da Argentina, aponta-o como figura mista, que está a meio caminho de ser o governador do departamento e o prefeito da capital departamental. A base para essas afirmações está no fato de a concentração populacional de Montevidéu se reproduzir em 12 dos outros 18 departamentos, nos quais as respectivas capitais concentram pelo menos $50 \%$ da população ${ }^{20}$.

O recorte temporal proposto tem como mote o fato de os dois países terem vivenciado alterações em seus sistemas políticos no final dos anos 1990 que aproximaram ainda mais as características associadas a essas autoridades.

No caso do Brasil, uma emenda à Constituição de 1988, promulgada em 1997, autorizou os chefes do executivo a concorreram, assim como no Uruguai, para mais um único mandato consecutivo. O instituto passou a ser aplicado para o cargo de prefeito desde o ano 2000. O país vizinho, por sua vez, permite a reeleição do intendente desde 1934.

20 Tal ocorre em: Artigas, Durazno, Maldonado, Paysandú, Salto, Tacuarembó, Treinta y Tres (cujas capitais têm o mesmo nome), mais Cerro Largo (capital Melo), Flores (Trinidad), Lavalleja (Minas) e Soriano (Mercedes) (URUGUAY. INE, 2010, 2018). 
A força do cargo: reeleição de chefes do executivo subnacional no Brasil e no Uruguai (2000-2016) | Alvaro Augusto de Borba Barreto

No Uruguai, as mudanças se deram no âmbito de ampla reforma constitucional, promulgada em janeiro de 1997 e, no caso dos departamentos, aplicada na eleição de 2000. Uma delas foi limitar a três o número máximo de candidatos que cada partido pode apresentar, quando anteriormente não havia qualquer restrição. A outra, introduzir o ODD (Órgão Deliberativo Departamental), um corpo responsável por indicar os candidatos a intendente, cuja composição é definida pelo eleitor comum nas primárias $^{21}$, e não pelos filiados aos partidos. Ressalva-se a diferença temporal entre a definição da composição do ODD e a tomada de decisão dele: as primárias se realizam em junho e a indicação dos candidatos tem o final de fevereiro do ano seguinte como prazo legal derradeiro. Como explica Cardarello (2009, p. 164),

esto obliga a los interesados, los precandidatos a intendente a marcar sus votos. Para ello deberán realizar una campaña y exhibir no solo sus intenciones de postularse, sino también sus credenciales, negociar apoyos, etc., casi un año antes de los comicios.

A terceira, e mais relevante para a questão em análise, foi separar no tempo as eleições para intendente da presidencial. Atualmente, eles ocorrem em maio, cerca de sete meses após a eleição nacional, realizada em outubro $^{22}$. Até 1994, ambas eram não só realizadas no mesmo dia como estavam eleitoralmente vinculadas, pois vigora o voto vinculado, fundido ou fusionado (COX, 1997, p. 42), que é a obrigatoriedade de o eleitor escolher a mesma legenda para todos os cargos em disputa, sob pena de anulação ${ }^{23}$.

Como afirmam Guerrini (2000, p. 187), Traversa (2001, p. 64), Cardarello (2001, p. 82), Cardarello e Magri (2010, p. 296-298) havia um efeito de arrasto da escolha do presidente sobre a de intendente, quase sempre a sorte do chefe do executivo departamental ficava associada ao desempenho dos candidatos presidenciais do partido, independentemente da

\footnotetext{
21 São organizadas pela Corte Eleitoral, em um mesmo dia de votação, com urnas comuns a todos os competidores. A participação é obrigatória para os partidos (que precisam alcançar 500 votos para se credenciarem às eleições propriamente ditas), mas facultativa ao eleitor. Além disso, as primárias (também chamadas de internas) são abertas: o eleitor vota no partido/candidato que quiser, sem a obrigação de estar a ele filiado (QUEIROLO; BOIDI; CASO, 2015, p. 59-60). Em cada partido, é selecionado: o candidato a presidente, o Órgão Deliberativo Nacional (ODN) e o ODD.

$22 \mathrm{Na}$ mesma data, são escolhidos outros dois cargos: os membros do órgão legislativo local, a Junta Departamental, chamados de edis; e os membros dos municípios existentes no respectivo departamento.

23 Apenas nos pleitos de 1946 e de 1950 foi permitido o chamado voto cruzado, que tornava possível escolher partidos diferentes nas eleições nacionais e nas departamentais (CARDARELLO, 2009, p. 176).
} 
A força do cargo: reeleição de chefes do executivo subnacional no Brasil e no Uruguai (2000-2016) | Alvaro Augusto de Borba Barreto

qualidade da gestão ou dos níveis de aprovação que ele registrava. Nas eleições de 1984, 1989 e 1994, em apenas dois departamentos o partido mais votado para presidente na localidade não ganhou também a intendência (MIERES, 2011, p. 66; POSE, 2013, p. 14).

Com a modificação, a eleição para intendente adquiriu uma autonomia potencial que era, até então, desconhecida ${ }^{24}$. Mieres (2011) comparou o partido vencedor da eleição nacional com o ganhador do pleito departamental, tendo verificado discordância de 38,6\% no período 19841994 e de 68,4\% de 1999-2010, quando passou a vigorar a separação temporal.

O Brasil há muitas décadas adota um período específico para os pleitos municipais, de modo que, a exemplo do que passou a ocorrer no Uruguai, a definição do prefeito está dissociada das demais ${ }^{25}$. Ela ocorre exatamente dois anos após a eleição nacional.

Apesar de ambos separarem no tempo as eleições nacionais e subnacionais, o Uruguai as realiza em um ciclo que dura 11 meses, ao fim do qual todos os mandatos estão renovados por cinco anos: ele começa com as primárias, que ocorrem em junho; prossegue com a eleição nacional, em outubro; o eventual $2^{\circ}$ turno da disputa presidencial, programado para novembro; e as subnacionais, previstas para maio do ano seguinte. Por sua vez, o Brasil distingue as disputas subnacionais em dois momentos (estadual, promovida concomitantemente com a nacional; e municipal), o que forma um calendário eleitoral bastante dinâmico, a partir dos quais o eleitorado retorna às urnas a cada biênio.

Outro ponto a demarcar é que no Uruguai, embora existam menos partidos do que no Brasil26, cada um pode lançar até três candidatos para intendente, como já foi informado. A motivação principal para tal regra é atender aos interesses das divisões internas dos partidos (chamadas de

\footnotetext{
24 Testam e confirma essa hipótese: López (2007) e Vairo (2008).

25 Nesse pleito também são definidos os vereadores, os membros da Câmara Municipal, que é o órgão unicameral legislativo de âmbito local. Ao inverso das Juntas Departamentais, que sempre possuem 31 membros, elas variam de nove a 55 vagas, conforme o tamanho da população do município.

26 Basicamente, três: Nacional, Colorado e Frente Ampla (PN, PC, FA), o que produz um sistema de pluripartidarismo moderado. Até 2019, havia outros dois partidos com pequena bancada no parlamento nacional (Independente e Assembleia Popular), mas que não elegeram intendente e tampouco possuem representação nas Juntas Departamentais. No Brasil, nada menos do que 30 partidos garantiram vaga na câmara baixa para a legislatura 2019-2023 (CAESAR, 2018). Em escala municipal, não é diferente: em 2016, 31 partidos elegeram ao menos um prefeito (UOL, 2016).
} 
A força do cargo: reeleição de chefes do executivo subnacional no Brasil e no Uruguai (2000-2016) | Alvaro Augusto de Borba Barreto

frações ou setores), instituições que têm respaldo eleitoral por meio do duplo voto simultâneo (DVS). Com este sistema, também chamado de voto preferencial intrapartidário, o eleitor escolhe um partido (lema, que é a denominação eleitoral dos competidores na legislação uruguaia) e um dos sublemas. Esses correspondem, normalmente, a uma fração, à parte de um setor ou à associação para fins eleitorais de diferentes setores, e que apresentam lista de concorrentes própria para o legislativo, candidato para cargo executivo ${ }^{27}$ ou apoiam algum dos concorrentes majoritários.

Por meio do DVS, todos os votos que eles obtêm são somados em beneficio do lema ${ }^{28}$ e contam para que garanta cadeira(s) legislativa(s), que é(são) distribuída(s) aos sublemas, proporcionalmente à participação de cada um no total de votos. No caso da eleição para intendente, o mecanismo é semelhante: somam-se os votos de cada candidato do lema, o partido mais votado ganha o pleito e o cargo é atribuído ao candidato mais votado do lema vencedor, ainda que, individualmente, ele não seja o mais votado. Isso porque os votos que ele obteve pessoalmente valem para alcançar a vitória dentro do lema, enquanto os votos do lema, para superar os demais partidos. Enfim, o DVS contempla duas disputas simultâneas, ambas decididas por maioria simples: entre os partidos e, no interior de cada um, entre os vários candidatos ou sublemas que ele apresentou (BUQUET, 2003).

Essa situação amplia o número potencial de candidatos, contempla e estimula disputas intrapartidárias, mas também torna possivel que um incumbent seja derrotado, mas o partido dele não, o que ocorre se o lema for o ganhador, mas se outro candidato do mesmo partido o superar na competição interna.

Isso não pode ocorrer no caso brasileiro, pois cada partido pode apresentar apenas um candidato a prefeito. Todavia, é prática corrente que os partidos coordenem suas estratégias e se associem para lançar um candidato comum, ou seja, formarem o que a legislação chama de coligação e a literatura de candidatura fusionada (COX, 1997). Essa aliança eleitoral

\footnotetext{
27 Após a reforma constitucional de 1997, exclusivamente nas disputas para intendente. No período anterior, também na eleição presidencial, em que vigorava o DVS. Aliás, foi a adoção da candidatura única a presidente dos partidos que motivou a adoção das primárias.

28 Há, ainda, a possibilidade de votar apenas no lema - equivalente ao voto de legenda no Brasil -, isto é, sem indicar sublema ou candidato em particular, o que também é contabilizado para o partido. Como explicam Buquet, Chasquetti e Moraes (1998, p. 12), "se realiza introduciendo hojas diferentes del mismo lema dentro de un sobre de votación".
} 
A força do cargo: reeleição de chefes do executivo subnacional no Brasil e no Uruguai (2000-2016) | Alvaro Augusto de Borba Barreto

também pode incluir a formação de lista comum de candidatos ao legislativo, o que permite acumular votos, de modo semelhante ao que ocorre com os sublemas uruguaios.

Em sintese: no Uruguai há menos partidos, sendo que cada um pode lançar mais de um candidato ao executivo subnacional; no Brasil, muitos, mas eles costumam apresentar candidatos em comum. Desse modo, ao contrário do que se poderia imaginar, no universo de casos analisados pela pesquisa, a média de candidatos por eleição foi maior no Uruguai do que no Brasil $(7,3 \text { a } 7,1)^{29}$.

\section{Delimitação da pesquisa}

A delimitação temporal proposta abarca cinco pleitos no Brasil (2000, 2004, 2008, 2012 e 2016) e quatro no Uruguai (2000, 2005, 2010 e 2015). Eles correspondem a todos os ocorridos após as mudanças institucionais referidas, ou seja, após a adoção de calendário autônomo em relação ao nacional e a adoção da possibilidade de reeleição imediata.

Como o foco está voltado à reeleição, é necessário considerar os pleitos imediatamente anteriores, haja vista que foram os chefes dos executivos subnacionais escolhidos nessas oportunidades (ou seus substitutos em definitivo) que puderam pleitear a permanência no cargo: o de 1996, em se tratando do Brasil; e o de 1994, no caso do Uruguai.

No entanto, as grandezas que envolvem os dois países são muito díspares: há 19 intendentes e cerca de 5.570 prefeitos. Para tornar razoável a comparação, a pesquisa selecionou o conjunto dos intendentes e prefeitos das 26 capitais estaduais. Dessa forma, a pesquisa se debruça sobre 206 eleições, das quais 130 do Brasil e 76 do Uruguai.

No caso do Brasil, o recorte também é motivado porque esses prefeitos compartilham o governo de localidades que possuem importância política regional, correspondem às localidades mais populosas ${ }^{30}$, apresentam grande influência econômica, além de concentrarem o poder administrativopolítico do próprio estado em que se inserem. Desse modo, aproximam-se

\footnotetext{
29 O dado é ilustrativo, mas também imperfeito, pois, em razão do DVS, são os partidos que disputam e ganham a intendência no Uruguai e apenas em um segundo momento, os candidatos. Levando isto em consideração, a média de competidores nominais do país é 4,2 , significativamente inferior à do Brasil.

30 As exceções são Florianópolis e Vitória, superadas, respectivamente, por Joinville e Vila Velha (sendo que esta pertence à região metropolitana de Vitória) (BRASIL. IBGE, 2019).
} 
A força do cargo: reeleição de chefes do executivo subnacional no Brasil e no Uruguai (2000-2016) | Alvaro Augusto de Borba Barreto

das características apresentadas pelos departamentos, vistas na seção anterior.

O trabalho adotou como parâmetro comparar os resultados obtidos nas eleições posteriores à conquista do cargo. Há duas situações a serem dimensionadas: a) o titular participa da disputa (há incumbent, portanto) ou b) não participa. O fato de ele não concorrer, por sua vez, deriva de duas situações: a) está inelegivel, pois acumula dois mandatos consecutivos; b) não se reapresenta, embora tivesse condições legais para tal.

Nessa última situação, o artigo procurou classificar qualitativamente as motivações que o movem. A primeira é decisão partidária, correspondente a titular que tem a intenção de concorrer, mas não é indicado pela entidade à qual está filiado. Na prática, houve impedimento, já que, como ponderado, inexistem candidaturas independentes nos dois países. A segunda é por decisão pessoal ou voluntária, que se refere a quem não concorre, embora a legislação o permitisse e o partido estivesse disposto a indicá-lo. A não apresentação pode ser a reação a constrangimentos percebidos pelo titular (envolvimento em escândalo e/ou denúncia, perda de apoio, evitar derrota provável, doença etc.) e que podem contrariar a sua própria ambição. Nesse sentido, pode não ser tão autônoma quanto a expressão induz a crer.

$\mathrm{O}$ incumbent pode alcançar dois resultados: a) vitória ou, simplesmente, ser reeleito; b) derrota. Em qualquer caso, a pesquisa busca identificar a força dos oponentes com os quais se defronta, dividindo-os em dois tipos: a) quem nunca exerceu o cargo em definitivo (desafiante); b) extitular que busca voltar ao cargo, chamado de antecessor.

A condição de desafiante está circunscrita ao cargo e ao município/departamento em questão. Logo, não inclui quem havia sido governante em outra localidade, foi ou é vice-prefeito/suplente de intendente. Entretanto, não indica alguém necessariamente sem carreira politica, pois a pesquisa encontrou: vereadores e edis, deputados, senadores, ex-ministros e até ex-governadores entre os desafiantes. Já ex-chefe do executivo local compreende aquele que exerceu o cargo em caráter definitivo, seja porque foi eleito ou nomeado (período ditatorial nos dois países), seja porque ascendeu ao cargo em substituição ao titular, mas não inclui substitutos pontuais e por tempo limitado. No Brasil, na falta do prefeito, 
A força do cargo: reeleição de chefes do executivo subnacional no Brasil e no Uruguai (2000-2016) | Alvaro Augusto de Borba Barreto

quem o substitui (permanentemente ou eventualmente) é o vice-prefeito, que foi eleito juntamente com o titular, em chapa indivisivel. No Uruguai, há quatro suplentes, previamente hierarquizados, também eleitos juntamente com o intendente (URUGUAY, 2018).

Há especificidades que precisam ser abordadas para fundamentar as escolhas metodológicas. A legislação eleitoral brasileira estabelece que o vice que substituir em definitivo o prefeito passa a exercer o $1^{\circ}$ mandato e, por isso, pode pleitear sucessivamente apenas mais um mandato. No caso do Uruguai, até agosto de 2004, não havia interpretação unívoca sobre essa situação, que era apreciada caso a caso pela Corte Eleitoral (INTENDENTES..., 2004). O cenário se alterou com a promulgação de lei que considera como mandato aquela substituição que contabiliza 30 meses de exercício consecutivo ou em períodos alternados (URUGUAY. PODER LEGISLATIVO, 2018), de modo a ser possivel acumular três períodos sequenciais (embora não completos). Em qualquer situação, quem está no exercício definitivo da intendência e pretender concorrer à reeleição precisa renunciar ao cargo no mínimo três meses antes do pleito. Nesse caso, é substituído por um dos suplentes, que vai completar o mandato e está automaticamente inelegivel ${ }^{31}$.

A questão se torna mais complexa, quando o intendente renuncia porque vai concorrer a deputado, o que é uma exigência constitucional ${ }^{32}$. Ele deixa o cargo no máximo ao final de julho - três meses antes da eleição nacional -, o que abrevia o mandato em quase um ano. Assim como no caso anterior, é substituído por um suplente, mas este é elegivel.

Os pesquisadores uruguaios não consideram essas substituições, de modo que, no pleito subsequente, classificam que não há incumbent em razão de inelegibilidade (CARDARELLO, 2009, 2013; PERMANYER, 2009, 2011; CARDARELLO; MAGRI, 2010, 2011; BALSA; MOREIRA; VIGNOLO, 2011; IRIGOIN, 2011; NIS; GRANJA, 2011; AGUIRRE, 2012, 2017; DOŠEK, 2014; CARDARELLO; FREIGEDO, 2016, 2017; BARRIOS; BERRÓN; RUIZ

\footnotetext{
31 No Brasil, o prefeito não é obrigado a se licenciar do cargo e tampouco a renunciar para concorrer à reeleição. Entretanto, é obrigado a renunciar para disputar qualquer outro cargo eletivo.

32 Se concorrer ao Senado, a Presidente ou a Vice-Presidente, ele não está obrigado a renunciar. A interpretação se funda no fato de serem cargos que representam o Estado como um todo, enquanto o de deputado, a unidade departamental, a mesma na qual o intendente exerce o governo (INTENDENTES ASPIRANTES..., 2004).
} 
A força do cargo: reeleição de chefes do executivo subnacional no Brasil e no Uruguai (2000-2016) | Alvaro Augusto de Borba Barreto

DÍAZ, 2017; PERMANYER; STUHLDREHER, 2017; NIS, 2017). Tais autores não ponderarem que, juridicamente, o substituto poderia concorrer e, se não o fez, teria ocorrido desistência mais do que inelegibilidade. Igualmente, não consideram que se o substituto concorrer, ele é o incumbent.

O entendimento do artigo é diferente. Explica-se. Esses casos de substituição em razão de renúncia do titular contemplam duas situações: a) substitutos politicamente comprometidos a não concorrer à reeleição e que completam o mandato, exercendo-o por aproximadamente $20 \%$ do período; b) aqueles que vão se lançar candidatos à reeleição.

Em condições normais, a modalidade de substituição está politicamente acordada. Isso porque a definição do ODD, responsável por indicar os candidatos a intendente, ocorre em junho. A renúncia do intendente e a respectiva substituição, até julho. Logo, quando ela se efetiva já é conhecida a correlação de forças entre os setores do partido, o que antecipa prováveis candidatos a serem oficializados pelo ODD até fevereiro do ano seguinte e exclui o pretendente que não obteve $30 \%$ dos convencionais (o limite mínimo para ser indicado).

Por esta razão, quando o substituto não é candidato, confirma-se a ausência do incumbent e, politicamente, a inelegibilidade - embora juridicamente ele pudesse concorrer e, portanto, tecnicamente, o que tenha ocorrido é a desistência. Pelo que foi exposto, a própria substituição já contempla tal perspectiva ${ }^{33}$.

Naqueles casos em que o substituto é candidato, o artigo preferiu classificá-lo como incumbent, divergindo dos demais pesquisadores. Corrobora tal escolha o fato de, por força constitucional, esse intendente ter de se afastar do cargo três meses antes do pleito, como o faz todo titular que concorre à reeleição. Contribui para este entendimento, ainda, a possibilidade que o substituto candidato tem de exercer o cargo durante algum tempo e se utilizar das potencialidades a ele associadas: visibilidade, manejo de recursos públicos, proposição e implantação de políticas públicas. $\mathrm{Na}$ mesma medida, ele pode capitalizar (ou ser penalizado por) resultados da

\footnotetext{
$33 \mathrm{O}$ mesmo vale para casos em que o intendente concorreu ao Senado, razão pela qual não precisou renunciar, mas acaba por fazê-lo ainda na vigência do mandato, com vistas a tomar posse no cargo nacional (o que ocorre a partir de fevereiro, enquanto o período como intendente se conclui em junho). Nessas situações, ele também é substituído por suplente que completa o período e não pode concorrer à reeleição.
} 
A força do cargo: reeleição de chefes do executivo subnacional no Brasil e no Uruguai (2000-2016) | Alvaro Augusto de Borba Barreto

gestão do antecessor, da qual provavelmente é reconhecido como continuidade.

Como expõe Irigoin (2011, p. 371), ao abordar o caso de um desses substitutos - Benjamin Irazábal (Durazno), que sucedeu a Carmelo Vidalín mas extensivel aos demais:

[...] tuvo en esta ocasión la posibilidad de culminar algunas de las obras del período y capitalizarlas a favor de su candidatura. Este fenómeno se produce por el tiempo transcurrido entre la elección interna y las municipales, que permiten a los intendentes que asumen en estos periodos preelectorales lograr llevar adelante parte de la administración y obtener cierto reconocimiento en la ciudadanía.

Reconhece-se que esse substituto não foi pessoalmente votado para o cargo, vindo a ocupá-lo em função de acordos políticos e o cumprimento de exigências legais. Igualmente, que ele tem menos tempo para se tornar conhecido como o novo titular e relativamente poucos meses para implantar a sua marca na gestão. Nesse sentido, ao buscar permanecer como intendente, ele é um incumbent em teoria menos potente do que o antecessor, que pode ser um neófito na política ou, no mínimo, alguém com menos experiência na condição de candidato ao cargo. Esta também é uma questão a ser verificada pela pesquisa.

Essa forma de contabilizar os casos implica aumentar a quantidade potencial de intendentes que buscam a reeleição e, consequentemente, a de resultados que o incumbent obteve. O efeito prático será apresentado na próxima seção.

Cabe informar, ainda, que não foi contabilizado como tentativa de retorno, quando o ex-chefe do executivo concorre a vice-prefeito ou a suplente de intendente, situações encontradas nos dois países (EXGOVERNADORA..., 2017; ASUMIÓ..., 2016).

No que tange aos partidos, a pesquisa precisou tomar decisões operacionais em relação ao Brasil, as quais não foram necessárias no caso do Uruguai.

A primeira indica que, como a intenção é verificar o resultado obtido na eleição seguinte pelo partido que havia elegido o prefeito, não são consideradas algumas modificações ocorridas ao longo do mandato. Essa ressalva é necessária porque o país convive com a chamada migração partidária, a situação em que o prefeito abandona o partido pelo qual se 
A força do cargo: reeleição de chefes do executivo subnacional no Brasil e no Uruguai (2000-2016) | Alvaro Augusto de Borba Barreto

elegeu, filia-se a outro e pleiteia a reeleição pela nova legenda ${ }^{34}$. Muitas vezes, tal mudança provoca o rompimento entre o prefeito e o partido "abandonado", razão pela qual eles se tornam ou podem se tornar adversários na nova eleição. Da mesma forma, costumeiramente quando há coligação, o vice-prefeito pertence a legenda diferente daquela do titular e a substituição implica a mudança do partido do titular do governo.

A segunda é que, quando o partido vencedor não apresenta candidato a prefeito no pleito subsequente, mas apoia formalmente concorrente de outra legenda, ponderou-se que o resultado obtido por esse candidato é o do partido que havia elegido o prefeito quatro anos antes. Na mesma linha, nos casos de fusões entre partidos ou de mudanças denominação, a nova organização foi apontada como sucessora da anterior.

Outra deliberação considerou como derrotados os partidos que, tendo elegido o prefeito, não participaram formalmente da eleição subsequente, ou seja, não apresentaram candidatos e tampouco compuseram coligação.

Os resultados referentes ao Brasil foram acessados no site do Tribunal Superior Eleitoral (TSE). Aqueles relativos ao Uruguai, no site da Corte Eleitoral. Fontes subsidiárias foram encontradas em sites e publicações, especialmente para identificar renúncia, afastamento e morte dos titulares, verificar condição e trajetória prévia dos candidatos.

\section{Resultados}

Inicialmente, a seção apresenta dados relativos às substituições dos eleitos. A seguir, traz aqueles alusivos aos que se encontravam impedidos de se reapresentar e aos que poderiam fazê-lo, mas preferiram não concorrer. Por fim, analisa os resultados obtidos pelos incumbents e seus oponentes (antecessor e desafiante) ${ }^{35}$.

\section{Substituições, inelegibilidades e desistências}

As substituições definitivas dos chefes do executivo validadas pela pesquisa estão sintetizadas a seguir.

\footnotetext{
34 No mesmo ciclo eleitoral, a legislação uruguaia estabelece a inelegibilidade de quem troca de partido, por meio do que Bottinelli (1999) chama de "cláusula antissecessão", pois a participação por um partido nas primárias serve como filiação válida em todo o ciclo. Todavia, ela pode ocorrer no intervalo entre os ciclos.

$35 \mathrm{Em}$ todas as tabelas, os números expressam percentual. O total, apresentado entre parênteses, número absoluto.
} 
A força do cargo: reeleição de chefes do executivo subnacional no Brasil e no Uruguai (2000-2016) | Alvaro Augusto de Borba Barreto

TABELA 1 - SUBSTITUIÇÃO DOS PREFEITOS DAS CAPITAIS ESTADUAIS E DOS INTENDENTES (BRASIL, URUGUAI, 2000-2016), EM PERCENTUAL

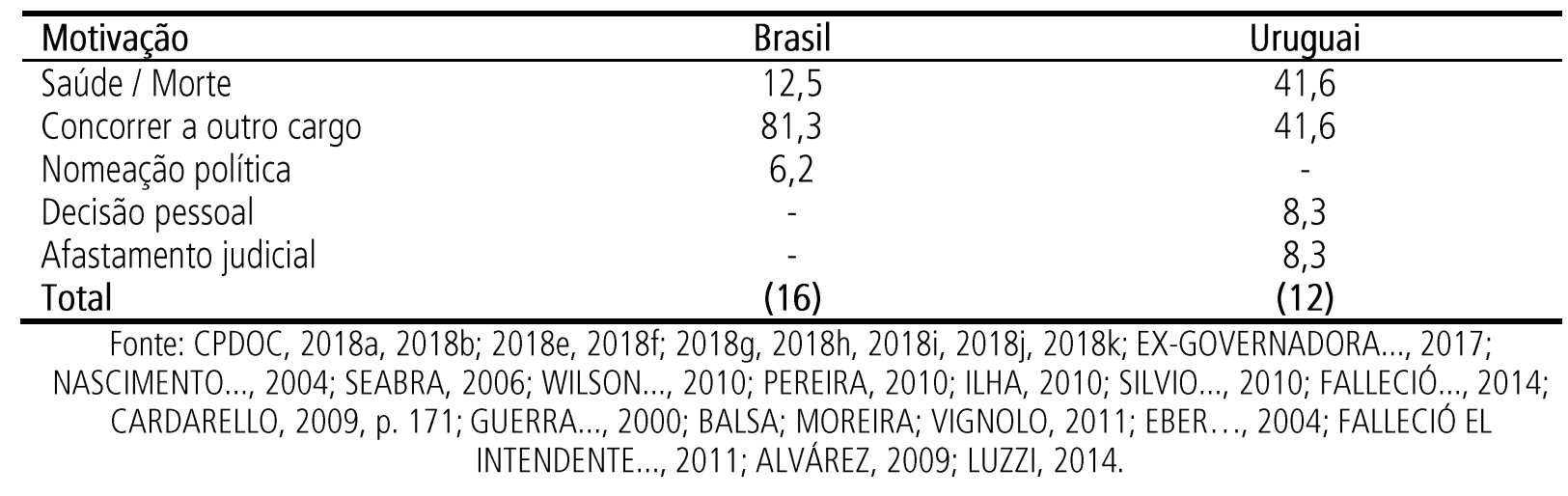

No Brasil, de 130 mandatos analisados, houve 16 substituições $(12,3 \%)$. Não foram registrados falecimentos, assim como afastamentos por ordem judicial ou por decisão do legislativo municipal ${ }^{36}$. As mudanças ocorreram por meio de renúncia; duas involuntárias (razões de saúde) e 14 voluntárias, sendo 13 para pleitear outro cargo eletivo durante o mandato (governador, 12 vezes; senador, uma), mais um caso em que o prefeito se afastou no último ano do $2^{\circ}$ mandato consecutivo para se tornar ministro.

No Uruguai, dos 76 períodos, em 12 (15,8\%) houve substituição do intendente ${ }^{37}$. Há proporcionalmente mais casos do que no Brasil e as mudanças abarcam situações mais díspares: cinco foram em razão de morte do titular; outras cinco abarcaram renúncia para participar das eleições nacionais, sendo que quatro cumpriram o ordenamento constitucional e um o fez por vontade própria, tendo em vista que concorreu a Senador. Finalmente, um renunciou menos de oito meses após ascender ao cargo e outro sofreu afastamento judicial.

TABELA 2 - CONDIÇÃO DOS PREFEITOS DAS CAPITAIS ESTADUAIS E DOS INTENDENTES NO QUE TANGE À REELEIÇÃO IMEDIATA POR OCASIÃO DO PLEITO (BRASIL, URUGUAI, 2000-2016), EM PERCENTUAL

\begin{tabular}{lcc}
\hline Situação & Brasil & Uruguai \\
\hline Elegível & 72,3 & 77,6 \\
Inelegível & 27,7 & 22,4
\end{tabular}

36 Houve dois casos de afastamento pela justiça, ambos ocorridos em 2012. Eles não foram contabilizados porque ocorreram após a eleição daquele ano e não interferiram no que aprecia a pesquisa (MICARLA..., 2012; PREFEITO DE PORTO..., 2012).

37 De fato, houve 13 substituições, pois em Cerro Largo (1995-2000), ocorreram dois casos: o intendente (Villanueva Saravia) faleceu e foi substituido pelo sogro, Serafin Bejerez $-2^{\circ}$ suplente, pois o $1^{\circ}$ também havia falecido -, que acabou afastado judicialmente. O cargo passou para Diego Saravia, $3^{\circ}$ suplente e pai de Villanueva (BOTTINELLI, 1998; GUERRA..., 2000). Como a unidade de análise é o mandato de intendente, foi contabilizada apenas uma, tendo-se optado pela $2^{\mathrm{a}}$, tendo em vista ser a derradeira no periodo. 
A força do cargo: reeleição de chefes do executivo subnacional no Brasil e no Uruguai (2000-2016) | Alvaro Augusto de Borba Barreto

Total

(130)

(76)

Fonte: BRASIL. TSE, 2018a; G1, 2018; URUGUAY. CORTE ELECTORAL, 2018; INSTITUTO DE CIÊNCIA POLÍTICA, 2000; BUQUET, 2005; BUQUET; JOHNSON, 2010; GARCÉ; JOHNSON, 2016; CARDARELLO; MAGRI, 2011; CARDARELLO; FREIGEDO, 2017; CPDOC, 2018a, 2018b; 2018e, 2018f; 2018g, 2018h, 2018i, 2018j, 2018k; EX-GOVERNADORA..., 2017; NASCIMENTO..., 2004; SEABRA, 2006; WILSON..., 2010; PEREIRA, 2010; ILHA, 2010; SILVIO..., 2010; FALLECIÓ..., 2014; CARDARELLO, 2009, p. 171; GUERRA..., 2000; BALSA; MOREIRA; VIGNOLO, 2011; EBER..., 2004; FALLECIÓ EL INTENDENTE..., 2011; ALVÁREZ, 2009; LUZZI, 2014; HOY..., 2004; INTENDENTES ASPIRANTES..., 2004; SOLO..., 2009; INTENDENTES DEPARTAMENTALES..., 2014; BOTTINELLI, 2015.

Os resultados da Tabela 2 se referem à situação em que os chefes do executivo chegaram à eleição seguinte. Eles revelam que, aproximadamente, um quarto deles estava inelegivel, pois exercia o que a respectiva lei nacional considera $2^{\circ}$ mandato consecutivo. No entanto, esses dados dizem respeito aos que aceitaram que não poderiam concorrer a novo mandato. A tabela a seguir enfoca outro momento temporal: registra os que não poderiam pleitear mais um período tão pronto obtiveram a reeleição, com vistas a mensurar a decisão tomada frente a tal cenário. Ela exclui os que faleceram ou deixaram o posto por razões de saúde, pois não tiveram a oportunidade de decidir.

TABELA 3 - CHEFES DOS PREFEITOS DAS CAPITAIS ESTADUAIS E DOS INTENDENTES INELEGÍVEIS NO INÍCIO DO MANDATO E DECISÃO TOMADA (BRASIL, URUGUAI, 1996-2015), EM PERCENTUAL

\begin{tabular}{lcc}
\hline Decisão & Brasil & Uruguai \\
\hline Cumprir o mandato & 71,4 & 50,0 \\
Buscar outro cargo & 28,6 & 50,0 \\
Total & $(49)$ & $(22)$ \\
\hline
\end{tabular}

Fonte: BRASIL. TSE, 2018a; G1, 2018; URUGUAY. CORTE ELECTORAL, 2018; INSTITUTO DE CIÊNCIA POLÍTICA, 2000; BUQUET, 2005; BUQUET; JOHNSON, 2010; GARCÉ; JOHNSON, 2016; CARDARELLO; MAGRI, 2011; CARDARELLO; FREIGEDO, 2017; CPDOC, 2018a, 2018b; 2018e, 2018f; 2018g, 2018h, 2018i, 2018j, 2018k; EX-GOVERNADORA..., 2017; NASCIMENTO..., 2004; SEABRA, 2006; WILSON..., 2010; PEREIRA, 2010; ILHA, 2010; SILVIO..., 2010; FALLECIÓ..., 2014; CARDARELLO, 2009, p. 171; GUERRA..., 2000; BALSA; MOREIRA; VIGNOLO, 2011; EBER..., 2004; FALLECIÓ EL INTENDENTE..., 2011; ALVÁREZ, 2009; LUZZI, 2014; HOY..., 2004; INTENDENTES ASPIRANTES..., 2004; SOLO..., 2009; INTENDENTES DEPARTAMENTALES..., 2014; BOTTINELLI, 2015.

O quadro revelado pela Tabela 3 é diferente em relação ao anterior. Dos prefeitos que estavam inelegiveis e tiveram possibilidade de decidir, $71,4 \%$ preferiram cumprir o mandato. No caso dos intendentes, o indice é $50 \%$.

A razão para esta diferença reside na estrutura de oportunidades ofertada pelo calendário eleitoral dos dois países, o que gera incentivos mais forte para que os intendentes tomem a decisão de buscar outro cargo do que o oferecido aos prefeitos. 
A força do cargo: reeleição de chefes do executivo subnacional no Brasil e no Uruguai (2000-2016) | Alvaro Augusto de Borba Barreto

No Uruguai, como todos os cargos são renovados no mesmo ciclo, aquele que renunciar durante o mandato perde menos de um ano de governo, mas pode ambicionar um novo posto e mais cinco anos na atividade eletiva. Porém, quem cumprir integralmente seu mandato ficará aproximadamente quatro anos e meio sem ocupar cargo eletivo.

Os prazos no Brasil são distintos e as situações mais dinâmicas. O prefeito que pleitear novo cargo durante o mandato deve renunciar no $16^{\circ}$ mês de governo e abdicar a 32 meses de atividade. Porém, se cumprir o mandato, a espera é mais curta e ele encontra amplo elenco de cargos à disposição: menos de dois anos depois, pode concorrer a: senador, deputado federal, deputado estadual, mais presidente, governador (e respectivos vices).

TABELA 4 - DECISÃO DOS PREFEITOS DAS CAPITAIS ESTADUAIS E DOS INTENDENTES QUANTO A BUSCAR A REELEIÇÃO IMEDIATA (BRASIL, URUGUAI, 2000-2016), EM PERCENTUAL

\begin{tabular}{lcc}
\hline Decisão & Brasil & Uruguai \\
\hline Concorrer & 84,0 & 83,1 \\
Não concorrer & 16,0 & 16,9 \\
Total & $(94)$ & $(59)$ \\
\hline
\end{tabular}

Fonte: BRASIL. TSE, 2018a; G1, 2018; URUGUAY. CORTE ELECTORAL, 2018; INSTITUTO DE CIÊNCIA POLITICA, 2000; BUQUET, 2005; BUQUET; JOHNSON, 2010; GARCÉ; JOHNSON, 2016; CARDARELLO; MAGRI, 2011; CARDARELLO; FREIGEDO, 2017; CPDOC, 2018a, 2018b; 2018e, 2018f; 2018g, 2018h, 2018i, 2018j, 2018k; EX-GOVERNADORA..., 2017; NASCIMENTO..., 2004; SEABRA, 2006; WILSON..., 2010; PEREIRA, 2010; ILHA, 2010; SILVIO..., 2010; FALLECIÓ..., 2014; CARDARELLO, 2009, p. 171; GUERRA..., 2000; BALSA; MOREIRA; VIGNOLO, 2011; EBER..., 2004; FALLECIÓ EL INTENDENTE..., 2011; ALVÁREZ, 2009; LUZZI, 2014; HOY..., 2004; INTENDENTES ASPIRANTES..., 2004; SOLO..., 2009; INTENDENTES DEPARTAMENTALES..., 2014; BOTTINELLI, 2015.

Os resultados relativos à decisão tomada pelos chefes do executivo que tinham condição legal de pleitear novo mandato consecutivo mostram equilíbrio entre os dois países: pouco mais de $83 \%$ dos prefeitos e dos intendentes se tornaram incumbent. O destino que eles tiveram será apreciado em breve. Agora, o foco se centra nos quase 17\% que abdicaram a tentar a reeleição imediata.

TABELA 5 - MOTIVAÇÃO PELA QUAL OS PREFEITOS DAS CAPITAIS ESTADUAIS E OS INTENDENTES DECIDIRAM NÃO CONCORRER À REELEIÇÃO IMEDIATA (BRASIL, URUGUAI, 2000-2016), EM PERCENTUAL

\begin{tabular}{lcc}
\hline Motivação & Brasil & Uruguai \\
\hline Pessoal & 80,0 & 60,0 \\
Partidária & 20,0 & 40,0 \\
Total & $(15)$ & $(10)$ \\
\hline
\end{tabular}

Fonte: DANTAS, 2002, p. 252-253; CPDOC, 2018c, 2018d; SOUZA; GERCHMANN, 2000; PREFEITO..., 2000; TOLEDO, 2000; BASTOS, 2013; FPA..., 2016; EM ENCONTRO..., 2012; TRIGUEIRO, 2012; AMAZONINO..., 2012; CARVALHO, 2013; 
A força do cargo: reeleição de chefes do executivo subnacional no Brasil e no Uruguai (2000-2016) | Alvaro Augusto de Borba Barreto

JOÃO..., 2012; PSB ANUNCIA..., 2016; CESAR..., 2016; EL TRIBUNAL..., 2001; BOTTINELLI, 2000; MALDONADO..., 2000; RUBEN..., 2000; XAVIER, 2013; CAMPANELLA..., 2000; HOY..., 2004; LAFLUF..., 2005; RICARDO..., 2011; LUZZI, 2013.

Os dados mostram a preponderância da motivação pessoal ou voluntária. Todavia, há diferenças sensiveis de intensidade: 80\% no Brasil e 60\% no Uruguai. Logo, proporcionalmente, há o dobro de impedimentos de reapresentação decididos pelo partido no Uruguai em comparação ao Brasil (40\% a 20\%). São indícios da maior relevância do partido em um país em comparação ao outro, especialmente frente à importância do titular do cargo, como o artigo pretende demonstrar na sua continuidade.

As desistências por motivação partidária no Uruguai abarcam duas situações básicas. A primeira é a derrota do intendente e do seu setor na formação do ODD, o que o deixa sem os votos necessários para ser indicado candidato. Ela abarca um caso. A segunda se refere a acordos intrapartidários, formulados antes das primárias, de modo que o intendente sequer delas participa como pretendente à indicação. Nos casos analisados, cobre três ocorrências.

No Brasil identificam-se as mesmas situações, tão somente com variação na intensidade em cada uma. A primeira abarca duas ocorrências: uma envolve prefeito que foi preterido nas primárias que o partido decidiu realizar38; a outra se refere a quem participou da convenção, mas foi derrotado. A segunda motivação abarca um caso, no qual acordos de cúpula impediram que o prefeito buscasse a indicação na convenção.

Se forem observados apenas as decisões pessoais, vai-se identificar algumas peculiaridades, verificáveis nos dois países, e que, na percepção da pesquisa, contribuem para a não apresentação. A primeira delas é o fato do desistente não ter sido o eleito para o cargo, e sim quem substituiu em definitivo o titular. No Brasil, de 12 desistências voluntárias, 25\% abarcam essa peculiaridade (três). No Uruguai, há mais incidências: 50\% (três de seis casos).

\footnotetext{
38 No país, não há o mecanismo das primárias obrigatórias e as indicações ocorrem na convenção partidária. Ocasionalmente, os partidos optam por definir seus candidatos em votação direta da qual participam os filiados, mas não há registro de primárias com a participação do eleitor em geral, a exemplo do que ocorre no Uruguai.
} 
A força do cargo: reeleição de chefes do executivo subnacional no Brasil e no Uruguai (2000-2016) | Alvaro Augusto de Borba Barreto

TABELA 6 - DECISÃO DOS SUBSTITUTOS EM DEFINITIVO DOS PREFEITOS DAS CAPITAIS ESTADUAIS E DOS INTENDENTES EM RELAÇÃO À REELEIÇÃO (BRASIL, URUGUAI, 2000-2016), EM PERCENTUAL

\begin{tabular}{lcc}
\hline Decisão & Brasil & Uruguai \\
\hline Desistente & 26,7 & 33,3 \\
Concorreu & 73,3 & 66,7 \\
Total & $(15)$ & $(12)$ \\
\hline
\end{tabular}

Fonte: BRASIL. TSE, 2018a; G1, 2018; URUGUAY. CORTE ELECTORAL, 2018; INSTITUTO DE CIÊNCIA POLÍTICA, 2000; BUQUET, 2005; BUQUET; JOHNSON, 2010; GARCÉ; JOHNSON, 2016; CARDARELLO; MAGRI, 2011; CARDARELLO; FREIGEDO, 2017; DANTAS, 2002, p. 252-253; CPDOC, 2018c, 2018d; SOUZA; GERCHMANN, 2000; PREFEITO..., 2000; TOLEDO, 2000; BASTOS, 2013; FPA..., 2016; EM ENCONTRO..., 2012; TRIGUEIRO, 2012; AMAZONINO..., 2012; CARVALHO, 2013; JOÃO..., 2012; PSB ANUNCIA..., 2016; CESAR..., 2016; EL TRIBUNAL..., 2001; BOTTINELLI, 2000; MALDONADO..., 2000; RUBEN..., 2000; XAVIER, 2013; CAMPANELLA..., 2000; HOY..., 2004; LAFLUF..., 2005; RICARDO..., 2011; LUZZI, 2013.

A fragilidade do substituto pode ser observada nos dados acima, que incluem, ainda, aqueles que não concorreram por decisão partidária. Aproximadamente de um quarto (Brasil) a um terço (Uruguai) não concorreu à reeleição. Lembra-se que o índice de desistência do conjunto dos chefes do executivo é bem menor: fica abaixo de 17\% (Tabela 4).

Pode-se especular o quanto essa peculiaridade não esconde alguém que circunstancialmente chegou ao cargo, mas que, sabedor de que não conseguiria a indicação do partido, evita a negativa e decide não se reapresentar ${ }^{39}$. Ou seja, de fato, seria incidência de motivação partidária, e não decisão pessoal.

TABELA 7 - DECISÃO DE PREFEITOS DAS CAPITAIS ESTADUAIS E INTENDENTES EM RELAÇÃO À PRÓXIMA ELEIÇÃO (BRASIL, URUGUAI, 2000-2016)

\begin{tabular}{lcc}
\hline Decisão & Brasil & Uruguai \\
\hline Concorrer & 60,8 & 64,5 \\
Inelegível & 27,7 & 22,4 \\
Desistir & 11,5 & 13,1 \\
Total & $(130)$ & $(76)$ \\
\hline
\end{tabular}

Fonte: BRASIL. TSE, 2018a; G1, 2018; URUGUAY. CORTE ELECTORAL, 2018; INSTITUTO DE CIÊNCIA POLÍTICA, 2000; BUQUET, 2005; BUQUET; JOHNSON, 2010; GARCÉ; JOHNSON, 2016; CARDARELLO; MAGRI, 2011; CARDARELLO; FREIGEDO, 2017.

\footnotetext{
39 Pode-se ilustrar com o caso de Camilo Tortorella (Maldonado), que substituiu, em 1998, o falecido intendente Burgueño. Manifestação dele indica que não teve meios para ser indicado pelo PN (MALDONADO..., 2000). A reforçar, Vairo e Pereyra (2011, p. 88) afirmam que "para las elecciones [de 2000], el grupo político de Burgueño propone a Enrique Antía, quien obtiene la victoria. Se trata de un caso en que gana las elecciones el candidato que aparece como heredero del intendente anterior, dentro de su partido. La campaña a la interna del PN se centró en Antía que no era reconocido en aquel momento como una figura politica importante dentro del PN, pero que tenía como principal ventaja el aparecer popularmente como símbolo de la herencia burgueñista (utilizaba una boina como simbolo de dicha herencia) y el ser apoyado fuertemente por los directores de la Intendencia".
} 
A força do cargo: reeleição de chefes do executivo subnacional no Brasil e no Uruguai (2000-2016) | Alvaro Augusto de Borba Barreto

Como saldo, pouco mais de $60 \%$ das eleições contaram com incumbent $(60,8 \%$ no Brasil e $64,5 \%$ no Uruguai), pois muitos titulares estavam inelegiveis $(27,7 \%$ e $22,4 \%$, respectivamente) ou, pelas razões vistas acima, não se reapresentaram $(11,5 \%$ e $13,1 \%)$.

\section{Vencedores}

Vistas estas situações, é preciso considerar quem venceu as eleições no periodo em análise, considerando três personagens: incumbent, antecessor, desafiante.

TABELA 8 - RESULTADO OBTIDO PELO INCUMBENT NAS CAPITAIS ESTADUAIS E INTENDÊNCIAS (BRASIL, URUGUAI, 2000-2016)

\begin{tabular}{lcc}
\hline Resultado & Brasil & Uruguai \\
\hline Vitória & 78,5 & 63,3 \\
Derrota & 21,5 & 36,7 \\
Total & $(79)$ & $(49)$ \\
\hline
\end{tabular}

Fonte: BRASIL. TSE, 2018a; G1, 2018; URUGUAY. CORTE ELECTORAL, 2018; INSTITUTO DE CIÊNCIA POLÍTICA, 2000; BUQUET, 2005; BUQUET; JOHNSON, 2010; GARCÉ; JOHNSON, 2016; CARDARELLO; MAGRI, 2011; CARDARELLO; FREIGEDO, 2017.

Os resultados mostram a força do titular do cargo que concorre à reeleição: no mínimo, ele vence aproximadamente dois terços dos pleitos. $\mathrm{O}$ prefeito apresenta taxa de sucesso significativamente superior à registrada pelo intendente $(78,5 \%$ a $63,3 \%)$, ou seja, o incumbent no Brasil tem conseguido se impor mais intensamente do que o equivalente do Uruguai. Esta questão será analisada com mais vagar na continuidade do texto.

$O$ foco a seguir passa a ser o confronto do incumbent com um antecessor. Os dados estão organizados pela presença de ex-prefeito ou de ex-intendente no pleito, sem se preocupar com a quantidade deles, pois há pleitos que contaram com mais de um antecessor.

TABELA 9 - ELEIÇÕES COM PARTICIPAÇÃO DE ANTECESSOR (BRASIL, URUGUAI, 2000-2016)

\begin{tabular}{|c|c|c|c|c|c|c|}
\hline \multirow[t]{2}{*}{ Situação } & \multicolumn{3}{|c|}{ Brasil } & \multicolumn{3}{|c|}{ Uruguai } \\
\hline & $\begin{array}{c}\text { Com } \\
\text { incumbent }\end{array}$ & $\begin{array}{c}\text { Sem } \\
\text { incumbent }\end{array}$ & Total & $\begin{array}{c}\text { Com } \\
\text { incumbent }\end{array}$ & $\begin{array}{c}\text { Sem } \\
\text { incumbent }\end{array}$ & Total \\
\hline Presença & 38,0 & 47,1 & 41,5 & 53,1 & 44,4 & 50,0 \\
\hline Ausência & 62,0 & 52,9 & 58,5 & 46,9 & 55,6 & 50,0 \\
\hline Total & (79) & (51) & (130) & (49) & (27) & (76) \\
\hline
\end{tabular}

Fonte: BRASIL. TSE, 2018a; G1, 2018; URUGUAY. CORTE ELECTORAL, 2018; INSTITUTO DE CIÊNCIA POLÍTICA, 2000; BUQUET, 2005; BUQUET; JOHNSON, 2010; GARCÉ; JOHNSON, 2016; CARDARELLO; MAGRI, 2011; CARDARELLO; FREIGEDO, 2017. 
A força do cargo: reeleição de chefes do executivo subnacional no Brasil e no Uruguai (2000-2016) | Alvaro Augusto de Borba Barreto

Há proporcionalmente mais eleições com a participação de antecessor no Uruguai do que no Brasil (50\% e 41,5\%). A diferença é mais significativa quando a eleição conta com incumbent. Nesse cenário, um antecessor se dispõe a participar em 53,1\% dos pleitos no primeiro e 38\% no segundo. Em outros termos: no Uruguai, a presença do incumbent serve de estímulo à participação do antecessor, enquanto a ausência reduz a tentativa de retorno; no Brasil, há o inverso, registram-se antecessor em $47,1 \%$ dos pleitos em que não há incumbent.

Dois fatores contribuem para essa diferença. O primeiro é a estrutura de oportunidades do Uruguai em relação ao Brasil: a quantidade de cargos eletivos oferecida pelo Uruguai é menor ${ }^{40}$, ao que se soma, no Brasil, um calendário que oferece mais chances, pois as eleições nacionais-estaduais e municipais se alternam a cada dois anos; No Uruguai, ele se comprime em um ciclo que se repete a cada cinco anos.

O segundo gira em torno de, no período analisado, o posto de intendente ter sido obtido por menor número de partidos (três), sendo que em 10 departamentos uma única legenda foi a vencedora. No Brasil, no recorte da pesquisa, 19 partidos elegeram prefeito nas capitais. Essa peculiaridade acirra a disputa entre os partidos nos departamentos em que há alternância entre os vencedores. Da mesma forma, produz competitividade naqueles em que há o predomínio de um único partido. Nesse caso, o confronto é intrapartidário, o que faz com que o ex-intendente de um setor venha a ser lançado para enfrentar o atual governante, que pertence a outra fração, em uma tentativa de evitar que antecipadamente o incumbent (e seu setor) se imponha.

TABELA 10 - TIPO DE COMPETIÇÃO DEPARTAMENTAL E PARTIDO DO ANTECESSOR EM COMPARAÇÃO AO DO INCUMBENT (URUGUAI, 2000-2015)

\begin{tabular}{lcc}
\hline Partido do antecessor & Com predomínio & Departamento \\
& 71,4 & Sem predomínio \\
\hline Mesmo & 14,3 \\
& \\
40 Sem contar postos nos municípios, provavelmente pouco atrativos, o Uruguai oferece: uma vaga de \\
presidente, outra de vice, 30 de senador (nacionais); mais uma de intendente, quatro de suplente, 31 \\
de edil (departamental) e as 99 de deputado, distribuídas por departamento (na maioria deles, há \\
apenas duas cadeiras disponiveis). O Brasil possui: uma vaga de presidente, outra de vice (nacionais), \\
três de senador, uma de governador, uma de vice-governador, de oito a 70 de deputados federais e de \\
24 a 94 de deputados estaduais, conforme a unidade da federação; mais uma de prefeito de capital, \\
uma de vice, de 9 a 55 de vereador. Sem contar os cargos nos aproximadamente 5.570 municipios e \\
que apenas excepcionalmente vão interessar ex-prefeitos de capitais.
\end{tabular}


A força do cargo: reeleição de chefes do executivo subnacional no Brasil e no Uruguai (2000-2016) | Alvaro Augusto de Borba Barreto

Outro $28,5 \quad 85,7$

Total (14) (14)

Fonte: URUGUAY. CORTE ELECTORAL, 2018; INSTITUTO DE CIEENCIA POLITICA, 2000; BUQUET, 2005; BUQUET; JOHNSON, 2010; GARCÉ; JOHNSON, 2016; CARDARELLO; MAGRI, 2011; CARDARELLO; FREIGEDO, 2017.

Como se observa, nos departamentos em que venceu sempre o mesmo partido ("com predomínio"), a competição entre incumbent e antecessor se processa majoritariamente no interior dessa legenda $(71,4 \%)$. Naqueles em que mais de um venceu, o confronto se dá majoritariamente entre membros de legendas diferentes $(85,7 \%)$ e há poucos confrontos intrapartidários ${ }^{41}$.

Em sintese: menos opções de carreira (cargos e oferta de eleições), menos departamentos com eleições competitivas e mais disputas intrapartidárias formam um conjunto que faz com que o confronto incumbent e antecessor seja mais recorrente no Uruguai do que no Brasil.

TABELA 11 - RESULTADO OBTIDO PELO ANTECESSOR QUE BUSCA REELEIÇÃO MEDIADA (BRASIL, URUGUAI, 2000-2016)

\begin{tabular}{|c|c|c|c|c|c|c|}
\hline \multirow[t]{2}{*}{ Resultado } & \multicolumn{3}{|c|}{ Brasil } & \multicolumn{3}{|c|}{ Uruguai } \\
\hline & $\begin{array}{c}\text { Com } \\
\text { incumbent }\end{array}$ & $\begin{array}{c}\text { Sem } \\
\text { incumbent }\end{array}$ & Total & $\begin{array}{c}\text { Com } \\
\text { incumbent }\end{array}$ & $\begin{array}{c}\text { Sem } \\
\text { incumbent }\end{array}$ & Total \\
\hline Vitória & 22,6 & 29,2 & 25,5 & 7,7 & 58,3 & 23,7 \\
\hline Derrota & 77,4 & 70,8 & 74,5 & 92,3 & 41,7 & 76,3 \\
\hline Total & (31) & (24) & (55) & (26) & (12) & (38) \\
\hline
\end{tabular}

Fonte: BRASIL. TSE, 2018a; G1, 2018; URUGUAY. CORTE ELECTORAL, 2018; INSTITUTO DE CIÊNCIA POLITIICA, 2000;

BUQUET, 2005; BUQUET; JOHNSON, 2010; GARCÉ; JOHNSON, 2016; CARDARELLO; MAGRI, 2011; CARDARELLO; FREIGEDO, 2017.

Os resultados obtidos por ex-prefeitos e ex-intendentes que buscaram retornar ao cargo reafirmam o equilíbrio entre os dois países: no Brasil, o índice de vitórias é 25,5\% e no Uruguai, 23,7\%.

Contudo, quando as disputas são distinguidas conforme a presença ou não do incumbent, os resultados são bastante diferentes. No Uruguai, o antecessor vence a maioria das eleições sem incumbent $(58,3 \%)$, mas perde quase todas as vezes em que o enfrenta (92,3\%). No Brasil, há mais equilíbrio: ele vence $29,2 \%$ dos pleitos em que se não se defronta com o incumbent; e 22,6\% das vezes em que disputa com ele, ou seja, ter estado no cargo não altera significativamente o desempenho.

41 Em dois departamentos com predomínio houve tanto confronto intrapartidário quanto interpartidário, situações contabilizadas na tabela. 
A força do cargo: reeleição de chefes do executivo subnacional no Brasil e no Uruguai (2000-2016) | Alvaro Augusto de Borba Barreto

O antecessor é adversário menos relevante do incumbent no Uruguai do que no Brasil. Se não há pretendente à reeleição imediata, o exintendente é forte competidor, o que não produz muita diferença no resultado dos ex-prefeitos.

A luz dos casos analisados, não se confirma a expectativa formulada por Cardarello (2009, p. 180), segundo a qual a presença do ex-intendente é fator que desafia o favoritismo do incumbent. Pode-se dizer que o antecessor é lançado com esta intenção, mas que ele não a tem conseguido efetivar.

TABELA 12 - RESULTADO OBTIDO PELO DESAFIANTE (BRASIL, URUGUAI, 2000-2016)

\begin{tabular}{lccc|ccc}
\hline Resultado & $\begin{array}{c}\text { Com } \\
\text { incumbent }\end{array}$ & $\begin{array}{c}\text { Brasil } \\
\text { Apenas com } \\
\text { ex-titular }\end{array}$ & $\begin{array}{c}\text { Apenas com } \\
\text { desafiante }\end{array}$ & $\begin{array}{c}\text { Com } \\
\text { incumbent }\end{array}$ & $\begin{array}{c}\text { Uruguai } \\
\text { Apenas com } \\
\text { ex-titular }\end{array}$ & $\begin{array}{c}\text { Apenas com } \\
\text { desafiante }\end{array}$ \\
\hline Vitória & 12,7 & 70,8 & 100 & 32,7 & 41,7 & 100 \\
Derrota & 87,3 & 29,2 & - & 67,3 & 58,3 & - \\
Total & $(79)$ & $(24)$ & $(27)$ & $(49)$ & $(12)$ & $(15)$ \\
\hline
\end{tabular}

Fonte: BRASIL. TSE, 2018a; G1, 2018; URUGUAY. CORTE ELECTORAL, 2018; INSTITUTO DE CIÊNCIA POLÍTICA, 2000;

BUQUET, 2005; BUQUET; JOHNSON, 2010; GARCÉ; JOHNSON, 2016; CARDARELLO; MAGRI, 2011; CARDARELLO; FREIGEDO, 2017.

Em todas as eleições houve a presença de desafiante, mas cabe ressalvar que em cerca de $20 \%$, apenas eles participaram, ou seja, incumbent e ex-titular não estavam presentes: 20,8\%, em se tratando de Brasil (27) e $19,7 \%$, do Uruguai (15). Obviamente, nesses casos, alguém que nunca havia exercido em definitivo o cargo se tornou vencedor.

A questão se volta para os resultados que ele alcançou, quando se defronta com titulares ou ex-titulares do executivo. No Uruguai, ele colhe mais derrotas frente a qualquer um desses adversários: 67,2\% quando há incumbent, 58,3\% quando há apenas ex-intendente. Isso não se repete no Brasil, onde ele perde intensamente para o incumbent $(87,3 \%)$, mas em pleitos que contam somente com ex-prefeito, supera-o em 70,8\% dos casos.

Da mesma forma, os indices de superioridade no confronto com os incumbents são distintos: no Brasil, o desafiante venceu 12,7\% dos embates; no Uruguai, 32,7\%. O significado é claro: apesar de perder a maior parte das vezes para o incumbent, o desafiante é adversário mais potente no Uruguai do que no Brasil.

Ao mesmo tempo, a Tabela 12 realça o que já havia sido revelado: todas as personagens vencem eleições, logo nenhuma delas em particular é 
A força do cargo: reeleição de chefes do executivo subnacional no Brasil e no Uruguai (2000-2016) | Alvaro Augusto de Borba Barreto

condição necessária e tampouco suficiente para a ocorrência do fenômeno, pois a participação do incumbent não é sinônimo de sucesso, assim como a de antecessor ou de ambos. É possivel, embora não recorrente, que quem jamais ocupou o cargo em definitivo supere os que já foram titulares.

QUADRO 1 - PERCENTUAL DE VITÓRIAS, CONFORME 0 COMPETIDOR (BRASIL, URUGUAI, 2000-2016)*

\begin{tabular}{|l|c|c|}
\hline Concorrente & Brasil & Uruguai \\
\hline Incumbent & 78,5 & 63,3 \\
\hline Ex-chefe do executivo & 25,5 & 23,7 \\
\hline Desafiante & 26,2 & 34,4 \\
\hline
\end{tabular}

* no caso do desafiante exclui as eleições em que só ele participa.

Fonte: BRASIL. TSE, 2018a; G1, 2018; URUGUAY. CORTE ELECTORAL, 2018; INSTITUTO DE CIÊNCIA POLÍTICA, 2000; BUQUET, 2005; BUQUET; JOHNSON, 2010; GARCÉ; JOHNSON, 2016; CARDARELLO; MAGRI, 2011; CARDARELLO; FREIGEDO, 2017.

O Quadro 1 confirma tal panorama. Ele traz o percentual de vitórias de cada competidor nos dois países, levando em consideração somente os pleitos em que há a presença de cada um e, no caso do desafiante, outro resultado era possivel. Há o predomínio do incumbent, mas este é mais eficiente no Brasil do que no Uruguai (78,5\% a 63,3\%), o que também ocorre no caso do desafiante $(34,4 \%$ e $26,2 \%$, respectivamente). O sucesso do antecessor é semelhante nos dois países (25,5\% e 23,7\%, respectivamente).

TABELA 13 - COMPETIDOR QUE DERROTA 0 INCUMBENT (BRASIL, URUGUAI, 2000-2016)

\begin{tabular}{lcc}
\hline Vencedor & Brasil & Uruguai \\
\hline Antecessor & 41,2 & 11,1 \\
Desafiante & 58,8 & 88,9 \\
Total & $(17)$ & $(18)$ \\
\hline
\end{tabular}

Fonte: BRASIL. TSE, 2018a; G1, 2018; URUGUAY. CORTE ELECTORAL, 2018; INSTITUTO DE CIÊNCIA POLÍTICA, 2000; BUQUET, 2005; BUQUET; JOHNSON, 2010; GARCÉ; JOHNSON, 2016; CARDARELLO; MAGRI, 2011; CARDARELLO; FREIGEDO, 2017.

Vistas essas questões, resta observar quais competidores conseguem superar o incumbent. Nos dois países, ele é derrotado proporcionalmente mais vezes por um desafiante, mas as diferenças são notáveis: no Brasil, este adversário responde por $58,8 \%$ das derrotas e no Uruguai, atinge $88,9 \%$. 
A força do cargo: reeleição de chefes do executivo subnacional no Brasil e no Uruguai (2000-2016) | Alvaro Augusto de Borba Barreto

TABELA 14 - VENCEDOR NAS ELEIÇÕES EM QUE PARTICIPAM INCUMBENTE ANTECESSOR (BRASIL, URUGUAI, 2000-2016)

\begin{tabular}{lcc}
\hline Vencedor & Brasil & Uruguai \\
\hline Incumbent & 58,1 & 61,5 \\
Antecessor & 22,6 & 7,7 \\
Desafiante & 19,3 & 30,8 \\
Total & $(31)$ & $(26)$ \\
\hline
\end{tabular}

Fonte: BRASIL. TSE, 2018a; G1, 2018; URUGUAY. CORTE ELECTORAL, 2018; INSTITUTO DE CIÊNCIA POLÍTICA, 2000; BUQUET, 2005; BUQUET; JOHNSON, 2010; GARCÉ; JOHNSON, 2016; CARDARELLO; MAGRI, 2011; CARDARELLO; FREIGEDO, 2017.

Como desdobramento da questão, a Tabela 14 se centra naqueles pleitos em que incumbent e antecessor se confrontaram. $\mathrm{O}$ primeiro comentário registra que o índice de sucesso do incumbent é semelhante nos dois países. O segundo é que o desafiante é mais bem-sucedido em superar os que já ocuparam o cargo no Uruguai do que no Brasil (30,8\% e 19,3\%, respectivamente). O terceiro é que, nesse cenário, o antecessor se mostra mais competitivo no Brasil $(22,6 \%)$ do que no Uruguai $(7,7 \%)$.

TABELA 15 - VENCEDOR DA ELEIÇÃO EM QUE PARTICIPA INCUMBENT, MAS NÃO ANTECESSOR (BRASIL, URUGUAI, 2000-2016)

\begin{tabular}{lcc}
\hline Vencedor & Brasil & Uruguai \\
\hline Incumbent & 91,7 & 65,2 \\
Desafiante & 8,2 & 34,8 \\
Total & $(48)$ & $(23)$ \\
\hline
\end{tabular}

Fonte: BRASIL. TSE, 2018a; G1, 2018; URUGUAY. CORTE ELECTORAL, 2018; INSTITUTO DE CIÊNCIA POLÍTICA, 2000;

BUQUET, 2005; BUQUET; JOHNSON, 2010; GARCÉ; JOHNSON, 2016; CARDARELLO; MAGRI, 2011; CARDARELLO; FREIGEDO, 2017

Quando há a participação do incumbent, mas não a de antecessor, os cenários entre os dois países voltam a se distinguir. $\mathrm{O}$ incumbent é competidor quase imbatível no Brasil (91,7\% de vitórias), o que não se verifica tão fortemente no Uruguai, embora ele vença a maioria das disputas $(65,2 \%)$. Como reverso, o desafiante prepondera em $34,8 \%$ dos pleitos no Uruguai e somente em $8,2 \%$ no Brasil. Como será explicado na sequência, o fator partido contribui decisivamente a este cenário.

\section{$O$ fator partido}

As diferenças registradas nos dois países podem ser compreendidas de modo mais amplo se for acrescentado elemento não priorizado na análise até o momento: o partido. 
A força do cargo: reeleição de chefes do executivo subnacional no Brasil e no Uruguai (2000-2016) | Alvaro Augusto de Borba Barreto

TABELA 16 - RESULTADO OBTIDO NA ELEIÇÃO SEGUINTE PELO PARTIDO QUE ELEGEU PREFEITO DA CAPITAL ESTADUAL OU INTENDENTE (BRASIL, URUGUAI, 2000-2016)

\begin{tabular}{|c|c|c|c|c|c|c|}
\hline \multirow[t]{2}{*}{ Resultado } & \multicolumn{3}{|c|}{ Brasil } & \multicolumn{3}{|c|}{ Uruguai } \\
\hline & $\begin{array}{c}\text { Com } \\
\text { incumbent }\end{array}$ & $\begin{array}{c}\text { Sem } \\
\text { incumbent }\end{array}$ & Total & $\begin{array}{c}\text { Com } \\
\text { incumbent }\end{array}$ & $\begin{array}{c}\text { Sem } \\
\text { incumbent }\end{array}$ & Total \\
\hline Vitória & 62,0 & 21,6 & 46,2 & 69,4 & 77,8 & 72,4 \\
\hline Derrota & 38,0 & 78,4 & 53,8 & 30,6 & 22,2 & 27,6 \\
\hline Total & (79) & (51) & (130) & (49) & (27) & (76) \\
\hline
\end{tabular}

Fonte: BRASIL. TSE, 2018a; G1, 2018; URUGUAY. CORTE ELECTORAL, 2018; INSTITUTO DE CIÊNCIA POLÍTICA, 2000; BUQUET, 2005; BUQUET; JOHNSON, 2010; GARCÉ; JOHNSON, 2016; CARDARELLO; MAGRI, 2011; CARDARELLO; FREIGEDO, 2017.

O primeiro ponto a destacar é a diferença no índice de vitórias do partido entre os dois países, bem mais intensa do que a registrada com o incumbent. Ele se mantém na intendência em $72,4 \%$ das disputas, enquanto preserva o cargo de prefeito em 46,2\%. Simbolicamente, no Uruguai, o partido vence mais vezes do que perde, ao contrário do que ocorre no Brasil.

O percentual de vitória da legenda no Uruguai é superior ao alcançado pelo incumbent $(72,4 \%$ e $63,3 \%$, respectivamente). Mais do que isso: ela vence mais vezes quando não conta com o titular que busca a reeleição $(77,8 \%$ a $69,4 \%)$, a preservar tendência que Cardarello (2009, p. 201) já havia identificado: a presença do incumbent não aumenta a probabilidade de sucesso do partido. Ou, melhor, ele consegue ser bemsucedido nas duas situações - e é mais vencedor se não há candidato à reeleição imediata. Isso também explica a razão pela qual o desafiante consegue ser mais eficiente no Uruguai: ele é guiado pela relevância do partido.

No caso do Brasil ocorre o contrário: o incumbent é mais vitorioso do que o partido $(78,5 \%$ e $46,2 \%$, respectivamente), o que se intensifica se a eleição conta ou não com a personagem (62\% e $21,6 \%$, respectivamente). Em outros termos: os partidos dependem intensamente do candidato para alcançar a vitória, o que não ocorre no caso uruguaio em que as duas personagens são fortes, mas as legendas se mostram ainda mais consistentes.

A consequência produzida por esses cenários foi demonstrada nos dados sobre os competidores. Há mais aproveitamento do incumbent no Brasil do que no Uruguai, embora ambos vençam a maioria das disputas. 
A força do cargo: reeleição de chefes do executivo subnacional no Brasil e no Uruguai (2000-2016) | Alvaro Augusto de Borba Barreto

Verifica-se semelhança no índice de êxito do antecessor nos dois países, o que indica a fragilidade contra qualquer competidor no Brasil, mas esconde a intensa variação que se verifica no Uruguai (limitação frente ao incumbent, mais eficiência quanto este não participa, ocasião em que o partido mostra a sua força).

Por fim, proporcionalmente, há mais vitórias do desafiante no Uruguai do que no Brasil, novamente sob impulso do partido, e mais variação neste segundo país, com poucos êxitos sobre o incumbent e muitos frente a ex-prefeito.

Contudo, as informações apresentadas acima estão baseadas na presença ou não do incumbent no pleito, mas não contempla uma peculiaridade verificada no Brasil: a mudança do partido no governo (em razão de o prefeito trocar de partido ao longo do mandato e/ou de ocorrer a mudança do titular). As tabelas a seguir atentam a esta particularidade e apresentam o resultado obtido pelo partido, quando ele é ou não o do incumbent.

TABELA 17 - RESULTADO OBTIDO NA ELEIÇÃO SEGUINTE PELO PARTIDO QUE ELEGEU PREFEITO DA CAPITAL ESTADUAL OU INTENDENTE SE CONTA OU NÃO COM INCUMBENT (BRASIL, URUGUAI, 20002016)

\begin{tabular}{lccc|ccc}
\hline Resultado & $\begin{array}{c}\text { É o do } \\
\text { incumbent }\end{array}$ & $\begin{array}{c}\text { Bão é o do } \\
\text { incumbent }\end{array}$ & Total & $\begin{array}{c}\text { Uruguai } \\
\text { É o do } \\
\text { incumbent }\end{array}$ & $\begin{array}{c}\text { Não é o do } \\
\text { incumbent }\end{array}$ & Total \\
\hline Vitória & 75,0 & 18,2 & 46,2 & 69,4 & 77,8 & 72,4 \\
Derrota & 25,0 & 81,8 & 53,8 & 30,6 & 22,2 & 27,6 \\
Total & $(64)$ & $(66)$ & $(130)$ & $(49)$ & $(27)$ & $(76)$ \\
\hline
\end{tabular}

Fonte: BRASIL. TSE, 2018a; G1, 2018; URUGUAY. CORTE ELECTORAL, 2018; INSTITUTO DE CIËNCIA POLIITICA, 2000; BUQUeT, 2005; BUQUET; JOHNSON, 2010; GARCÉ; JOHNSON, 2016; CARDARELLO; MAGRI, 2011; CARDARELlO; FREIGEDO, 2017.

O novo cenário intensifica o que o anterior já explicitava: ser o partido do incumbent é fator determinante para a continuidade do partido no governo das capitais estaduais brasileiras. Quando tem esta condição, vence $75 \%$ das disputas; se não a possui, perde $81,8 \%$ das vezes. Anteriormente, considerando se o incumbent participa do pleito, os índices eram $62 \%$ e $78,4 \%$, respectivamente.

Mais alguns dados podem consolidar o que já foi ponderado. Eles se baseiam em peculiaridades do sistema político de cada país que tornam 
A força do cargo: reeleição de chefes do executivo subnacional no Brasil e no Uruguai (2000-2016) | Alvaro Augusto de Borba Barreto

possivel desvincular os resultados do partido e do incumbent. No Uruguai, ela deriva da autorização para que o partido lance mais de um candidato a intendente, o que se confirma em 43 das 49 eleições com incumbent $(87,8 \%)$. No Brasil, há 15 casos em que na eleição subsequente, fruto da migração partidária realizada pelo prefeito $\mathrm{e} / \mathrm{ou}$ da troca de titular, ocorre enfrentamento com o partido vencedor do pleito anterior.

TABELA 18 - VENCEDOR DAS ELEIÇÕES EM QUE É POSSÍVEL DESVINCULAR O RESULTADO DO PARTIDO GANHADOR DO PLEITO ANTERIOR E O DO INCUMBENT (BRASIL, URUGUAI, 2000-2016)

\begin{tabular}{lcc}
\hline Vencedor & Brasil & Uruguai \\
\hline Incumbent & 93,3 & - \\
Partido & 6,7 & 7,0 \\
Ambos & - & 58,1 \\
Nenhum & - & 34,9 \\
Total & $(15)$ & $(43)$ \\
\hline
\end{tabular}

Fonte: BRASIL. TSE, 2018a; G1, 2018; URUGUAY. CORTE ELECTORAL, 2018; INSTITUTO DE CIÊNCIA POLÍTICA, 2000; BUQUET, 2005; BUQUET; JOHNSON, 2010; GARCÉ; JOHNSON, 2016; CARDARELLO; MAGRI, 2011; CARDARELLO; FREIGEDO, 2017.

Nem todas as alternativas que compõem a Tabela 18 são equivalentes nos dois países. É impossivel que apenas o incumbent vença no Uruguai, dado que nenhum deles trocou de partido ao longo do mandato e não existem candidaturas independentes. No Brasil, é impossível que ambos vençam, pois só figuram as situações em que os resultados se tornam dissociáveis e eles se enfrentam (embora possam compartilhar a derrota frente a terceiro).

Apesar disso, a Tabela traz resultados suficientes para esclarecer o que o artigo almeja, pois mostra que, no Brasil, quando é possivel dissociar os resultados do candidato e do partido, a preponderância do incumbent é contundente: ele se reelegeu em 93,3\% das vezes (14 em 15). No Uruguai, dá o contrário: embora seja recorrente a possibilidade de partido e incumbent apresentarem resultados diferentes, em $93 \%$ das vezes isto não se confirma e ambos compartilharam a derrota ou a vitória. Nas poucas oportunidades em que a dissociação ocorre (três vezes), prevalece o partido - como não poderia ser diferente -, a indicar que o incumbent foi superado na disputa intrapartidária. 
A força do cargo: reeleição de chefes do executivo subnacional no Brasil e no Uruguai (2000-2016) | Alvaro Augusto de Borba Barreto

TABELA 19 - RESULTADO OBTIDO PELO INCUMBENT NA DISPUTA INTRAPARTIDÁRIA (URUGUAI, 20002015)

\begin{tabular}{lc}
\hline Mais votado do partido & $\%$ \\
\hline Sim & 88,4 \\
Não & 11,6 \\
Total & $(43)$ \\
\hline Fonte: URUGUAY. CORTE ELECTORAL, 2018; INSTITUTO DE CIÉNCIA POLIITICA, 2000; BUQUET, 2005; BUQUET; JOHNSON, \\
2010; GARCÉ; JOHNSON, 2016; CARDARELLO; MAGRI, 2011; CARDARELLO; FREIGEDO, 2017.
\end{tabular}

Esse cenário é explicitado pela Tabela 19: o incumbent prevaleceu na grande maioria das disputas nas quais o partido apresenta mais de um candidato $(88,4 \%)^{42}$. Apenas cinco não o conseguiram: além dos três superados quando o partido venceu, vistos acima, há outros dois duplamente derrotados: na competição intrapartidária e na interpartidária.

Pode-se especificar os poucos casos em que, nos dois países, o incumbent foi derrotado. No Uruguai, todas ocorreram no PN e dois dos três derrotados eram substitutos definitivos do intendente que faleceu ou renunciou ao cargo para participar da eleição nacional (Alejandro Giorello, que não se reelegeu em 2000; Oscar Ximenes, derrotado em 2010, coincidentemente, ambos eram intendentes de Lavalleja). Ainda assim, a condição de incumbent mostrou a sua força: Giorello, que governou por quase três anos, obteve $49,1 \%$ dos votos do partido em 2000 , tendo sido derrotado por Vergara, reconhecido como o herdeiro do intendente falecido, por escassa vantagem (431 votos) (CARDARELLO, 2009, p. 186) ${ }^{43}$.

O terceiro caso ocorreu com Jorge Cerdeña, em San José, na eleição de 2000. Ele foi derrotado pelo ex-intendente Juan Chiruchi $(1984,1989)$. Segundo Cardarello (2009, p. 180), mais do que um antigo governante, ele era o verdadeiro caudilho departamental, tendo exercido o cargo durante a ditadura, indicado pelos militares, e nele se mantido pelas urnas na retomada das eleições diretas, em 1984. No quinquênio em que esteve fora da intendência (1994-2000), concorreu a vice-presidente (1994), atuou como senador e ministro. Como complementam Perdomo e Garracini (2011, p. 297),

\footnotetext{
42 A este contingente podem ser somados os seis que foram candidatos únicos, pois, antecipadamente, eles eliminam o risco de serem derrotados na disputa interna, assim como o domínio que têm sobre o partido.

43 Ximenes, que atuou como intendente por um ano, mostrou-se um competidor frágil: obteve 12,4\% dos votos e foi largamente superado pela outra candidata do partido, Adriana Peña.
} 
A força do cargo: reeleição de chefes do executivo subnacional no Brasil e no Uruguai (2000-2016) | Alvaro Augusto de Borba Barreto

la historia electoral de San José en el periodo post-dictadura no puede entenderse sin hacer referencia al líder político indiscutido de este periodo, Chiruchi, quien no solo administró los destinos del departamento durante 20 años, sino que en las ocasiones que no pudo presentarse como candidato (elecciones de 1994 y 2010) ganaron los postulantes a quienes el caudillo apoyó explícita y públicamente.

Em outros termos: após ter lançado Cerdeña como seu delfim, que até então era secretário-geral do seu governo, Chiruchi fez valer a sua condição de líder e o derrotou nas urnas para retornar ao cargo. Ainda assim, não foi uma vitória esmagadora: apesar da relativa fragilidade do incumbent frente a este oponente, ele alcançou $41,8 \%$ dos votos, a comprovar, mais uma vez, a importância de quem está no cargo.

No Brasil, o único caso de incumbent derrotado pelo partido ocorreu em Teresina, na eleição de 2012. E, mais uma vez, tratou-se de um prefeito que substituiu o titular. Elmano Férrer era o vice de Silvio Mendes, do Partido da Social-Democracia Brasileira (PSDB), tendo se tornado prefeito em 2010. No pleito seguinte, ele concorreu à reeleição, enquanto o antigo partido governante lançou candidatura própria (Firmino Filho), que o derrotou.

Não foi uma ocorrência fortuita, pois o PSDB vinha elegendo o prefeito de Teresina consecutivamente há cinco disputas (1992, 1996, 2000, 2004 e 2008), tendo deixado a titularidade apenas em razão da renúncia do eleito em 2008, que foi substituído pelo vice ${ }^{44}$. Além disso, Firmino Filho havia sido eleito prefeito em 1996 e em 2000 e, por ocasião da disputa, atuava como deputado estadual. Ainda assim, a exemplo do que foi registrado no Uruguai, o peso do incumbent se fez valer: Férrer foi derrotado no $2^{\circ}$ turno, tendo obtido $48,4 \%$ dos votos, a menor diferença em prol do PSDB dentre todas as vitórias que ele obteve no municipio, incluindo a de 2016.

\section{Conclusão}

O artigo comparou 130 eleições para prefeito das capitais estaduais do Brasil e 76 para intendentes dos departamentos do Uruguai, ocorridas no período 2000-2016, tendo como mote mudanças institucionais que

\footnotetext{
44 PSDB repetiu o feito em 2016, consolidando sete vitórias consecutivas na capital do Piauí. Trata-se do único caso em que o mesmo partido ganhou todas as eleições analisadas em uma capital, o que aproxima da situação de domínio unipartidário vivenciada em vários departamentos uruguaios. Mais detalhes, ver: Martins (2016).
} 
A força do cargo: reeleição de chefes do executivo subnacional no Brasil e no Uruguai (2000-2016) | Alvaro Augusto de Borba Barreto

aproximaram essas autoridades unipessoais que chefiam o poder executivo subnacional: a possibilidade de uma reeleição imediata e calendário próprio em relação ao pleito nacional.

O foco esteve centrado no incumbent. Observou que há quantidade semelhante de inelegibilidades decorrentes do acúmulo de dois mandatos consecutivos (aproximadamente um quarto dos casos). Identificou que $71,4 \%$ dos prefeitos que atingem essa condição cumprem integralmente o mandato, índice que cai a 50\% em se tratando de intendentes. A diferença decorre da estrutura de oportunidades menos custosa oferecidas pelo Brasil.

A intensidade de chefes do executivo que, tendo condições legais, apresentam-se à reeleição imediata é semelhante e gira em torno de $83 \%$. No entanto, há diferenças nas motivações pelas quais alguns não concorrem: embora haja a preponderância de decisão própria nos dois países, registramse proporcionalmente o dobro de impedimentos decorrentes de decisão partidária no Uruguai em relação ao Brasil.

Em termos de taxa de sucesso do incumbent, o cenário é idêntico, com vitória dele na maioria das disputas, o que corrobora a literatura resenhada e que destaca o sucesso dessa personagem e aponta a vantagem estratégica que ela possui. E, mais uma vez, ressalvada esta semelhança, há diferenças de intensidade: prefeitos são mais bem-sucedidos do que os intendentes $(78,5 \%$ a $63,3 \%)$.

O estudo também apreciou o desempenho de outras duas personagens, antecessor e desafiante. Foram abordadas três situações: quando um e/ou o outro enfrenta o incumbent e como se saem quando o pleito não tem a presença do concorrente à reeleição imediata. Os resultados mostraram diferenças. Nos dois países, o incumbent é o principal vencedor, independentemente do adversário, mas há mais tentativas de retornar no Uruguai do que no Brasil (50\% dos pleitos analisados e 41,5\%, respectivamente). Antecessor perde quase sempre que se defrontam com o titular do cargo e obtém mais vitórias quando ele não participa da disputa no Uruguai (92,3\% e 58,3\%), situações que não alteram o cenário no Brasil (22,6\% e 29,2\% de vitórias do antecessor, respectivamente). Já o desafiante consegue ganhar mais disputas no Uruguai do que no Brasil, seja ao considerar o conjunto de pleitos, seja ao verificar o confronto dele com 
A força do cargo: reeleição de chefes do executivo subnacional no Brasil e no Uruguai (2000-2016) | Alvaro Augusto de Borba Barreto

incumbent. Porém, frente ao ex-chefe do executivo, ele se mostra pouco competitivo.

Tais diferenças se explicam pelo papel distinto que os partidos desempenham nos dois países. A pesquisa identificou que o incumbent é mais relevante para a obtenção das vitórias no Brasil, enquanto no Uruguai prepondera o partido. Este vence $72,4 \%$ das disputas, sendo que alcança $77,8 \%$ sem o incumbent e $69,4 \%$ com. Ou seja, obtém mais êxitos quando não conta com o titular que busca permanecer no cargo. No Brasil, o índice geral de vitórias do partido fica em $46,2 \%$, atingindo $75 \%$ quando ele é o do incumbent e somente $18,2 \%$ quando não conta com este ativo.

Esta tendência pode ser observada nos pleitos em que os resultados do partido e do candidato vencedor há quatro anos podem se desassociar. Nessas situações, o partido ganha em situações residuais e de praticamente a mesma intensidade nos dois países (7\%), mas é um único caso no Brasil e três no Uruguai, sendo que no primeiro há um confronto efetivo entre partido e incumbent e no segundo, não.

Desse modo, verifica-se que desenhos institucionais que possuem uma série de traços que podem ser relacionados produzem resultados distintos no que tange à reapresentação e aos resultados colhidos pelos titulares de cargos executivos que buscam a reeleição, assim como em relação ao índice de vitórias de antecessores e/ou desafiantes. É o que se observou na apreciação dos casos dos prefeitos e dos intendentes, no período 2000-2016.

\section{Referências:}

AGUIRRE, Oscar. Durazno. 2010-2015: de la continuidad al cambio. In: CARDARELLO, Antonio; FREIGEDO, Martin (Coord.). El desafio de un cambio - elecciones departamentales y municipales de 2015. Montevideo: Instituto de Ciencia Política; Congreso de Intendentes, 2017, p. 427-445.

AGUIRRE, Oscar. Sistema electoral, fraccionalización y formación del gobierno municipal. Estudio de un caso: Durazno (2000-2012). 2012. Monografia (Licenciatura em Ciência Política). Universidad de la República Montevideo.

ALVÁREZ, Cecilia. Otra vuelta. La Diaria, 07 dic. 2009. Disponível em: $<$ https://ladiaria.com.uy/articulo/2009/12/otra-vuelta/>. Acesso em: 08 dez. 2018. 
A força do cargo: reeleição de chefes do executivo subnacional no Brasil e no Uruguai (2000-2016) | Alvaro Augusto de Borba Barreto

AMAZONINO Mendes desiste de disputar reeleição em Manaus. Folha de São Paulo, 01 jul. 2012. Disponível em: <http://www1.folha.uol.com.br/poder/2012/07/1113438-amazoninomendes-desiste-de-disputar-reeleicao-em-manaus.shtml>. Acesso em: 08 dez. 2018.

ANASTASIA, Fátima; MELO, Carlos Ranulfo Felix; SANTOS, Fabiano. Governabilidade e representação política na América do Sul. Rio de Janeiro; São Paulo: Fundação Konrad Adenauer; Unesp, 2004.

ARAÚJO JÚNIOR, Ary Francisco de; CANÇADO, Paulo; SHIKIDA, Cláudio Djissey. Economics and Politics: o que determina as chances de reeleição em municípios? O caso das eleições municipais de Minas Gerais - 2000. Informe Gepec, v. 9, n. 2, 2005.

ASUMIÓ Alejandro Giorello como intendente de Lavalleja. El Bocón, 07 mar. 2016. Disponivel em: <http://www.elbocon.com.uy/noticias/articulo/1100/asumio-alejandrogiorello-como-intendente-de-lavalleja>. Acesso em: 08 dez. 2018.

BALSA, Silvana; MOREIRA, Ramiro; VIGNOLO, Alejandro. El retorno del "larrañaguismo". Elecciones departamentales y municipales 2010 en Paysandú. In: CARDARELLO, Antonio; MAGRI, Altaïr (Coord.). Cambios, certezas e incertidumbres - elecciones departamentales y municipales de 2010. Montevideo: Instituto de Ciencia Politica; Congreso de Intendentes, 2011, p. 217-236.

BARRETO, Alvaro Augusto de Borba. Desenho institucional, expectativas e impasses na criação do município no Uruguai (2009-2014). Revista Sulamericana de Ciência Política, v. 3, n. 1, p. 39-66, 2015.

BARRETO, Alvaro Augusto de Borba. Destinos cruzados: partidos e candidatos nas eleições para prefeito no Brasil e intendente no Uruguai (2000-2012). Revista Debates, v. 8, n. 1, p. 105-125, jan.-abr. 2014.

BARRETO, Alvaro Augusto de Borba. Eleições municipais comparadas: a escolha do chefe do executivo no Brasil e no Uruguai e o impacto sobre os sistemas partidários locais (2000-2005). Revista Brasileira de Ciência Política, n. 7, p. 285-318, jan.-abr. 2012.

BARRETO, Alvaro Augusto de Borba. Reeleição para o executivo municipal no Brasil (2000-2008). Revista Debates, v. 3, n. 2, p. 97-115, jul.-dez, 2009.

BARRIOS, Sabrina; BERÓN, Maria Elena; RUIZ DÍAZ, Matías. Un Departamento cada vez menos blanco. Las elecciones departamentales y municipales 2015 en Soriano. In: CARDARELLO, Antonio; FREIGEDO, Martin (Coord.). El desafio de un cambio - elecciones departamentales y municipales de 2015. Montevideo: Instituto de Ciencia Política; Congreso de Intendentes, 2017, p. 296-321.

BASTOS, Fernanda. João Verle analisa volta do déficit nas finanças de Porto Alegre. Jornal do Comércio, 30 set. 2013. Disponivel em: 
A força do cargo: reeleição de chefes do executivo subnacional no Brasil e no Uruguai (2000-2016) | Alvaro Augusto de Borba Barreto

$<$ http://jcrs.uol.com.br/site/noticia.php?codn=135681>. Acesso em: 08 dez. 2018.

BORBA, Felipe; CERVI, Emerson Urizzi. Relação entre propaganda, dinheiro e avaliação de governo no desempenho de candidatos em eleições majoritárias no Brasil. Opinião Pública, v. 23, n. 3, p. 754.785, set.-dez. 2017.

BOTTINELLI, Oscar. Los problemas de cambio de titularidad en las intendencias departamentales. 21 agosto 2015. Disponivel em: $<$ http://factum.uy/analisis/2015/ana150821.php>. Acesso em: $08 \mathrm{dez}$. 2018.

BOTTINELLI, Oscar. Los juicios de gestión de los intendentes salientes de Montevideo y Canelones. 10 marzo 2000. Disponivel em: $<$ https://www.factum.uy/edicionesanteriores/encuepol/elec99/2000/ele00003.html>. Acesso em: $18 \mathrm{dez}$. 2018.

BOTTINELLI, Oscar. El ciclo electoral 1999-2000 y el sistema de partidos. In: INSTITUTO DE CIENCIA POLÍTICA. Elecciones 1999-2000. Montevideo: Instituto de Ciencia Política; Banda Oriental, 2000, p. 13-26.

BOTTINELLI, Oscar. Los efectos políticos de la reforma constitucional. 1999. Disponivel em: <https://www.factum.uy/edicionesanteriores/estpol/sispol/sip99001.html>. Acesso em: 08 dez. 2018.

BOTTINELLI, Oscar. La crisis institucional de Cerro Largo. 18 agosto 1998. Disponível em: <https://www.factum.uy/edicionesanteriores/estpol/anapol/1998/anp98023.html>. Acesso em: 08 dez. 2018.

BRAMBOR, Thomas; CENEVIVA, Ricardo. Incumbency Advantage in Brazilian Mayoral Elections. In: American Political Science Association's 2011 Annual Meeting, 2011. Disponivel em: <http://papers.ssrn.com/sol3/papers.cfm?abstract_id=1903410>. Acesso em: 20 jul. 2020.

BRAMBOR, Thomas; CENEVIVA, Ricardo. Reeleição e continuísmo nos municípios brasileiros. Novos Estudos, n. 93, p. 9-21, jul. 2012.

BRASIL. IBGE. Estatísticas. 2019. Disponivel em: <https://www.ibge.gov.br/index.php>. Acesso em: 08 out. 2019.

BRASIL. TSE (TRIBUNAL SUPERIOR ELEITORAL). Eleições. 2018a. Disponivel em: <http://www.tse.jus.br/eleicoes/eleicoes-anteriores/eleicoesanteriores>. Acesso em: 08 dez. 2018.

BRASIL. TSE. Municípios com mais de 200 mil eleitores - eleição 2016. 2018b. Disponivel em: <http://www.justicaeleitoral.jus.br/arquivos/municipios-com-mais-de-200mil-eleitores>. Acesso em: 08 dez. 2018. 
A força do cargo: reeleição de chefes do executivo subnacional no Brasil e no Uruguai (2000-2016) | Alvaro Augusto de Borba Barreto

BRENDER, Adi; DRAZEN, Allan. How do budget deficits and economic growth affect reelection prospects? Evidence from a large cross-section of countries. National Bureau of Economic Research, Working Paper 11862, 2005. Disponível em: <https://www.nber.org/papers/w11862>. Acesso em: 20 jul. 2020.

BUQUET, Daniel (Coord.). Las claves del cambio. Ciclo electoral y nuevo gobierno 2004-2005. Montevideo: Banda Oriental; Instituto de Ciencia Política, 2005.

BUQUET, Daniel. El doble voto simultáneo. Revista SAAP, v. 1, n. 2, p. 317 339, 2003.

BUQUET, Daniel; CHASQUETTI, Daniel; MORAES, Juan Andres. Fragmentación política y gobierno en el Uruguay: ¿un enfermo imaginario? Montevideo: Facultad de Ciencias Sociales, 1998.

BUQUET, Daniel; JOHNSON, Niki (Org.). Del cambio a la continuidad - ciclo electoral 2009-2010 en Uruguay. Montevideo: Fin de Siglo; Clacso; Instituto de Ciencia Politica, 2010.

CAESAR, Gabriela. Eleições 2008 - saiba como eram e como ficaram as bancadas na Câmara dos Deputados, partido a partido. G1, 08 out. 2018. Disponivel em: <https://g1.globo.com/politica/eleicoes/2018/eleicao-emnumeros/noticia/2018/10/08/pt-perde-deputados-mas-ainda-tem-maiorbancada-da-camara-ps1-de-bolsonaro-ganha-52-representantes.ghtml>. Acesso em: 08 dez. 2018.

CAMPANELLA declinó su candidatura a la comuna. La Red 21, 15 feb. 2000. Disponivel em: <http://www.1r21.com.uy/politica/2956-campanella-declinosu-candidatura-a-la-comuna>. Acesso em: 08 dez. 2018.

CARDARELLO, Antonio. La cuenta de pérdidas y ganancias. El Frente Amplio y la elección de gobiernos departamentales en 2010. Revista Iberoamericana de Estudios Municipales, n. 8, p. 79-122, 2013.

CARDARELLO, Antonio. La reelección inmediata del ejecutivo a nivel subnacional. Un estudio de tres casos. 2009. Tese (Doutorado em Ciência Política). Universidade Federal do Rio Grande do Sul - Porto Alegre.

CARDARELLO, Antonio. Entre la continuidad y la disidencia: perfiles de campaña en Maldonado, Paysandú, Salto y Colonia. In: LAURNAGA, Maria Elena (Coord.). La geografia de un cambio. Política, gobierno y gestión municipal en Uruguay. Montevideo: Banda Oriental, 2001, p. 73-88.

CARDARELlO, Antonio; FREIGEDO, Martin (Coord.). El desafio de un cambio - elecciones departamentales y municipales de 2015. Montevideo: Instituto de Ciencia Política; Congreso de Intendentes, 2017.

CARDARELLO, Antonio; FREIGEDO, Martin. El escenario subnacional en transformación: las reformas institucionales $y$ su impacto en la 
A força do cargo: reeleição de chefes do executivo subnacional no Brasil e no Uruguai (2000-2016) | Alvaro Augusto de Borba Barreto

configuración del mapa político en Uruguay. Revista Uruguaya de Ciencia Política, v. 25, p. 157-181, jul. 2016.

CARDARELLO, Antonio; GUERRINI, Aldo. Las elecciones internas en el interior: todo el poder a los intendentes. Observatorio Político, La politica en el umbral del cambio, Informe de Coyuntura. Montevideo: Banda Oriental; Instituto de Ciencia Política, n. 5, p. 141-145, oct. 2004.

CARDARELLO, Antonio; MAGRI, Altaïr (Coord.). Cambios, certezas e incertidumbres - elecciones departamentales y municipales de 2010. Montevideo: Instituto de Ciencia Politica; Congreso de Intendentes, 2011.

CARDARELLO, Antonio; MAGRI, Altaïr. Elecciones departamentales 2010: consecuencias imprevistas, resultados esperados. In: BUQUET, Daniel; JOHNSON, Niki (Org.). Del cambio a la continuidad - ciclo electoral 20092010 en Uruguay. Montevideo: Fin de Siglo; Clacso; Instituto de Ciencia Politica, 2010, p. 295-324.

CAREY, John. The reelection debate in Latina America. Latin American Politics and Society, v. 45, n. 1, p. 119-133, 1993.

CARVALHO, Cefas. Micarla encerra carreira que já tinha sido encerrada. Potiguar Notícias, 30 abr. 2013. Disponivel em: $<$ http://www.potiguarnoticias.com.br/noticias/23351/micarla-encerracarreira-que-ja-tinha-sido-encerrada\%3E>. Acesso em: 08 dez. 2018.

CASTELAR, Pablo Urano de Carvalho; MONTEIRO, Vitor Borges; JORGE NETO, Paulo de Melo. Reeleição municipal e performance como prefeito: educação e saúde como determinantes do sucesso eleitoral. Economia Ensaios, v. 34, n. 2, p. 30-57, jan.-jun. 2020.

CAVAlCANTE, Pedro. Desempenho fiscal e eleições no Brasil: uma análise comparada dos governos municipais. Revista de Administração Pública, v. 50, n. 2, p. 307-330, mar.-abr. 2016.

CAVAlCANTE, Pedro. Vale a pena ser um bom prefeito? Comportamento eleitoral e reeleição no Brasil. Opinião Pública, v. 21, n. 1, p. 87-104, abril 2015.

CESAR Souza Jr. anuncia oficialmente que desiste de concorrer à reeleição em Florianópolis. DC, 08 jun. 2016. Disponível em: $<$ http://dc.clicrbs.com.br/sc/noticias/noticia/2016/06/cesar-souza-jranuncia-oficialmente-que-desiste-de-concorrer-a-reeleicao-em-florianopolis5898323.html>. Acesso em: 08 dez. 2018.

CHASQUETTI, Daniel. Democracia, presidencialismo y partidos politicos en América Latina: evaluando la "difícil combinación". Montevideo: Instituto de Ciencia Politica, 2008.

CONCEIÇÃO, Bruno da Silva. Sistema eleitoral e reeleição nas eleições municipais de 2012 para o executivo no Brasil. Revista Eletrônica de Ciência Política, v. 6, n. 1, p. 11-25, 2015. 
A força do cargo: reeleição de chefes do executivo subnacional no Brasil e no Uruguai (2000-2016) | Alvaro Augusto de Borba Barreto

COPPEDGE, Michael. Partidos latinoamericanos: darwinismo político en la década perdida. Revista Argentina de Ciencia Politica. Buenos Aires, n. 4, p. 113-146, dic. 2000.

COSTA, Mylena Moreira de Alencastro. Reeleição e politica fiscal: um estudo dos efeitos da reeleição nos gastos públicos. 2006. Dissertação (Mestrado em Economia do Setor Público). Universidade de Brasília. Brasília.

COX, Gary W. Make votes count: strategic coordination in the world's electoral systems. Cambridge: Cambridge Oxford Press, 1997.

CPDOC (Centro de Pesquisa e Documentação de História Contemporânea do Brasil). ERSE, Chiquilito (Verbete). 2018a. Disponivel em: <http://www.fgv.br/cpdoc/acervo/dicionarios/verbete-biografico/ersechiquilito>. Acesso em: 08 dez. 2018.

CPDOC. CASTRO, Célio de (Verbete). 2018b. Disponivel em: $<$ http://www.fgv.br/cpdoc/acervo/dicionarios/verbete-biografico/castrocelio-de>. Acesso em: 08 dez. 2018.

CPDOC. ALBERNAZ, Nion (Verbete). 2018c. Disponivel em: <http://www.fgv.br/cpdoc/acervo/dicionarios/verbete-biografico/albernaznion>. Acesso em: 08 dez. 2018.

CPDOC. ROCHA, Manoel Odir (Verbete). 2018d. Disponivel em: <http://www.fgv.br/cpdoc/acervo/dicionarios/verbete-biografico/rochamanuel-odir>. Acesso em: 08 dez. 2018.

CPDOC. GENRO, Tarso (Verbete). 2018e. Disponivel em: <http:/ /www.fgv.br/cpdoc/acervo/dicionarios/verbete-biografico/tarsofernando-herz-genro>. Acesso em: 08 dez. 2018.

CPDOC. MELO, Flaviano (Verbete). 2018f. Disponivel em: <http:/ /www.fgv.br/cpdoc/acervo/dicionarios/verbete-biografico/meloflaviano>. Acesso em: 08 dez. 2018.

CPDOC. LAGO, Jackson (Verbete). 2018g. Disponivel em: $<$ http://www.fgv.br/cpdoc/acervo/dicionarios/verbete-biografico/jacksonkepler-lago>. Acesso em: 08 dez. 2018.

CPDOC. DÉDA, Marcelo (Verbete). 2018h. Disponivel em: $<$ http://www.fgv.br/cpdoc/acervo/dicionarios/verbete-biografico/marcelodeda-chagas $>$. Acesso em: 08 dez. 2018.

CPDOC. JUCÁ, Teresa (Verbete). 2018i. Disponível em: $<$ http:/ / www.fgv.br/cpdoc/acervo/dicionarios/verbete-biografico/teresasaenz-surita-juca>. Acesso em: 08 dez. 2018.

CPDOC. RESENDE, Iris (Verbete). 2018j. Disponivel em: <http://www.fgv.br/cpdoc/acervo/dicionarios/verbete-biografico/irisresende-machado>. Acesso em: 08 dez. 2018. 
A força do cargo: reeleição de chefes do executivo subnacional no Brasil e no Uruguai (2000-2016) | Alvaro Augusto de Borba Barreto

CPDOC. COUTINHO, Ricardo (Verbete). 2018k. Disponível em: $<$ http://www.fgv.br/cpdoc/acervo/dicionarios/verbete-biografico/coutinhoricardo>. Acesso em: 08 dez. 2018.

DANTAS, Ibarê. Eleições em Sergipe - 1985-2000. Rio de Janeiro: Tempo Brasileiro, 2002.

DELIBERADOR, Giuliano Savioli; KOMATA, Nicanor Barry. Reeleição nas eleições municipais de 2008. In: CAGGIANO, Monica Herman Salem (Org.). Comportamento Eleitoral. Barueri: Manole, 2010. p. 63-90.

DIAS, Bruno Pires; NOSSA, Valcemiro; MONTE-MOR, Danilo Soares. O investimento público influencia na reeleição? Um estudo empírico nos municípios do estado do Espírito Santo. Revista de Administração Pública, v. 52, n. 5, p. 880-898, set.-out. 2018.

DOŠEK, Tomas. Sistema de partidos multinivel en Uruguay (1984-2010) desafio del Frente Amplio y adaptación de los partidos tradicionales en un escenario congruente. In: FREIDENBERG, Flavia; SUÁREZ-CAO, Julieta (Org.). Territorio y poder: nuevos actores y competencia política en los sistemas de partidos multinivel en América Latina. Salamanca: Universidad de Salamanca, 2014, p. 291-338.

DOWNS, Anthony. Teoria econômica da democracia. São Paulo: Edusp, 1999.

DUVERGER, Maurice. Os partidos políticos. 3ed. Rio de Janeiro: Guanabara, 1987.

EATON, Kent. Politics beyond the capital. The design of subnational institutions in South America. Stanford: Stanford University, 2004.

EBER da Rosa y Mazzulo se dispiden. La Red 21, 29 jul. 2004. Disponível em: <http://www.lr21.com.uy/politica/149081-eber-da-rosa-y-mazzulo-sedespiden>. Acesso em: 08 dez. 2018.

EL TRIBUNAL de cuentas a favor de subsidio para Diego Saravia. La Red 21, 06 enero 2001. Disponivel em: <http://www.lr21.com.uy/politica/32826-eltribunal-de-cuentas-a-favor-de-subsidio-para-diego-saravia>. Acesso em: 08 dez. 2018.

EM ENCONTRO, petebista já lança Norma Galindo à prefeitura ou vice. Blog do Romilson, 22 maio 2012.2 Disponivel em: <http://www.rdnews.com.br/blog-do-romilson/conteudo/em-encontropetebista-ja-lanca-norma-galindo-a-prefeita-ou-vice/34783>. Acesso em: 08 dez. 2018.

EX-GOVERNADORA do RN, Wilma de Faria morre em Natal. G1, 16 jun. 2017. Disponível em: <https://g1.globo.com/rn/rio-grande-donorte/noticia/ex-governadora-do-rn-wilma-de-faria-morre-em-natal.ghtml>. Acesso em: 08 dez. 2018. 
A força do cargo: reeleição de chefes do executivo subnacional no Brasil e no Uruguai (2000-2016) | Alvaro Augusto de Borba Barreto

FALLECIÓ EL INTENDENTE electo de Flores. El Observador, 11 abr. 2011. Disponivel em: <https://www.elobservador.com.uy/nota/fallecio-elintendente-electo-de-flores-20114111920>. Acesso em: 08 dez. 2018.

FALLECIÓ exintendente de Rivera Walter Riesgo. El Pais, 27 jul. 2014. Disponivel em: <https://web.archive.org/web/20161001174847/http://www.elpais.com.uy /informacion/fallecio-walter-riesgo.html>. Acesso em: 08 dez. 2018.

FEREJOHN, John. Incumbent performance and electoral control. Public Choice, v. 50, n. 1-3, p. 5-25, 1986.

FIORINA, Morris P. Retrospective voting in American national elections. New Haven: Yale University Press, 1981.

FIRPO, Sergio; PIERI, Renan; SOUZA, André Portela. Electoral impacts of uncovering public school quality: evidence from Brazilian municipalities. Economia, v. 18, n. 1, p. 1-17, 2017.

FPA lança chapa majoritária com Marcus Alexandre e Socorro Neri. Acreaovivo.com, 04 jul. $2016 . \quad$ Disponivel: <http://www.acreaovivo.com/noticia/fpa-lanca-chapa-majoritaria-commarcus-alexandre-e-socorro-neri/14548>. Acesso em: 08 dez. 2018.

G1. Eleições 2016. 2018. Disponível em: <http://g1.globo.com/politica/eleicoes/2016/>. Acesso em: 08 dez. 2018.

GARCÉ, Adolfo; JOHNSON, Niki (Coord.). Permanencias, transiciones y rupturas - elecciones en Uruguay 2014/5. Montevideo: Instituto de Ciencia Politica; Fin de Siglo, 2016.

GINSBURG, Tom; MELTON, James; ELKINS, Zachary. On the evasion of executive term limits. William and Mary Law Review, v. 52, n. 6, p. 18071872, 2010-2011.

GUERRA entre Bejérez y Diego Saravia. La Red 21, 26 enero 2000. Disponivel em: <http://www.lr21.com.uy/politica/1329-guerra-entrebejerez-y-diego-saravia>. Acesso em: 08 dez. 2018.

GUERRINI, Aldo. El peso político de los intendentes del interior: apuntes para una discusión a la luz de las últimas consultas electorales In: INSTITUTO DE CIENCIA POLÍTICA. Elecciones 1999-2000. Montevideo: Banda Oriental; Instituto de Ciencia Política, 2000, p. 185-193.

HAMILTON, Alexander. Artigo LXXII In: MADISON, J.; HAMILTON, A.; JAY, J. Os artigos federalistas. Rio de Janeiro: Nova Fronteira, 1993.

HOTT, Henrique Augusto Campos Fernandez. Migração partidária e resultados de politica: evidência para municípios brasileiros. 2018. Dissertação (Mestrado em Economia). Universidade de São Paulo. Ribeirão Preto. 
A força do cargo: reeleição de chefes do executivo subnacional no Brasil e no Uruguai (2000-2016) | Alvaro Augusto de Borba Barreto

HOY, jornada clave para algunos intendentes blancos y colorados. La Red 21, 29 jul. 2004. Disponivel em: <http://www.lr21.com.uy/politica/149080hoy-jornada-clave-para-algunos-intendentes-blancos-y-colorados $>$. Acesso em: 08 dez. 2018.

ILHA, Flávio. Fogaça deixa prefeitura de Porto Alegre; PDT volta a governar após 22 anos. Uol Notícias, 29 mar. 2010. Disponivel em: <https://noticias.uol.com.br/politica/ultimas-noticias/2010/03/29/viceassume-prefeitura-de-porto-alegre-nesta-terca-pdt-volta-a-governar-apos-22anos.htm>. Acesso em: 08 dez. 2018.

INSTITUTO DE CIENCIA POLÍTICA. Elecciones 1999-2000. Montevideo: Banda Oriental; Instituto de Ciencia Política, 2000.

INTENDENTES respaldan el proyecto de reelección de jefes comunales interinos. La Red 21, 09 enero 2004. Disponivel em: $<$ http://www.1r21.com.uy/politica/129325-intendentes-respaldan-elproyecto-de-reeleccion-de-jefes-comunales-interinos $>$. Acesso em: 08 dez. 2018.

INTENDENTES ASPIRANTES a la deputación dejan sus cargos. La Red 21, 16 jul. 2004. Disponivel em: <http://www.1r21.com.uy/politica/147791intendentes-aspirantes-a-la-diputacion-dejan-sus-cargos $>$. Acesso em: 08 dez. 2018.

INTENDENTES DEPARTAMENTALES. Varios renuncian por elecciones nacionales de octubre. Uruguay Escribe, 24 jul. 2014. Disponivel em: <http://uruguayescribe.blogspot.com/2014/07/intendentesdepartamentales-varios.html>. Acesso em: 08 dez. 2018.

IRIGOIN, Pablo. Los mismos vientos soplan en Durazno. Departamentales y municipales 2010. In: CARDARELLO, Antonio; MAGRI, Altaïr (Coord.). Cambios, certezas e incertidumbres - elecciones departamentales y municipales de 2010. Montevideo: Instituto de Ciencia Política; Congreso de Intendentes, 2011, p. 365-385.

JOÃO da Costa afirma que candidato do PT no Recife será Humberto. G1, 05 jun. 2012. Disponivel em: <http://g1.globo.com/pernambuco/noticia/2012/06/joao-da-costa-afirmaque-candidato-do-pt-no-recife-sera-humberto.html>. Acesso em: 08 dez. 2018.

JONES, Mark. Electoral laws and the effective number of candidates in presidential elections. The Journal of Politics, v. 61 n. 1, p. 171-184, feb. 1999.

KESTLER, Thomas; LUCCA, Juan Bautista; KRAUSE, Silvana. 'Break-in parties' and changing patterns of democracy in Latin America. Brazilian Political Science Review, v. 10, n.1, p. 2016. 
A força do cargo: reeleição de chefes do executivo subnacional no Brasil e no Uruguai (2000-2016) | Alvaro Augusto de Borba Barreto

KLEIN, Fábio Alvim. Reelection incentives and political budget cycle: evidence from Brazil. Revista de Administração Pública, v. 44 n.2, p. 283337, mar-abril, 2010.

KLEIN, Fabio Alvim; SAKURAI, Sergio Naruhiko. Term limits and political budget cycles at the local level: evidence from a young democracy. European Journal of Political Economy, v. 37, p. 21-36, 2015.

LAFLUF ganó en Río Negro. La Red 21, 09 mayo 2005. Disponível em: $<$ http:/ /www.lr21.com.uy/politica/175398-lafluf-gano-en-rio-negro>. Acesso em: 08 dez. 2018.

LANZARO, Jorge (Ed.). Social democracias "tardías": Europa Meridional y América Latina. Madrid: Centro de Estudios Politicos y Constitucionales, 2014.

LANZARO, Jorge (Ed.). Tipos de presidencialismo y coaliciones politicas en América Latina. Buenos Aires: Clacso, 2001.

LAURNAGA, María Elena; GUERRINI, Aldo. Del "buen vecino" al "intendente emprendedor": el rol de los intendentes departamentales en la reforma del Estado. Revista Uruguaya de Ciencia Política, n. 7, p. 83-93, 1994.

LAUTENSCHLAGE, Jonatan. O oportunismo pré-eleitoral em nivel das despesas públicas compensa na busca pela reeleição nos municípios catarinenses no século XXI? Textos de Economia, v. 22 n. 1, p. 113-140, 2019.

LIMA, Ana Patrícia Pierre. A influência da educação na reeleição dos prefeitos cearenses no ano de 2012. 2018. Dissertação (Mestrado Profissional em Economia do Setor Público). Universidade Federal do Ceará. Fortaleza.

LINZ, Juan. Presidencialismo ou parlamentarismo: faz alguma diferença? In: LAMOUNIER, Bolivar (Org.). A Opção parlamentarista. São Paulo: Sumaré, 1991.

LÓPEZ, Santiago. ¿Cuán "locales" son las elecciones municipales en Uruguay? Estimando independencia de resultados y comportamientos electorales. Revista Uruguaya de Ciencia Política, n. 16, p. 73-101, 2007.

LUZZI, Leonardo. Intendentes dejan sus cargos para postularse al parlamento. El Observador, 12 jun. 2014. Disponível em: <https://www.elobservador.com.uy/nota/intendentes-dejan-sus-cargospara-postularse-al-parlamento-201461218450>. Acesso em: 08 dez. 2018.

LUZZI, Leonardo. Frente ya maneja nombres para la IMM y nadie habla de reelección. El Observador, 14 abr. 2013. Disponível em: <https://www.elobservador.com.uy/nota/frente-ya-maneja-nombres-parala-imm-y-nadie-habla-de-reeleccion-201341420480>. Acesso em: $08 \mathrm{dez}$. 2018. 
A força do cargo: reeleição de chefes do executivo subnacional no Brasil e no Uruguai (2000-2016) | Alvaro Augusto de Borba Barreto

MACHADO, Mônica. A retórica da reeleição: mapeando os discursos dos Programas Eleitorais (HGPE) em 1998 e 2006. Opinião Pública, v. 15, n. 1, p. 159-189, jun. 2009.

MAGALHÃES, Leandro de. Incumbency effects in Brazilian mayoral elections: a regression discontinuity design. Bristol: CMPO, University of Bristol, 2012. (Working Paper 12/284.). Disponivel em: <http://www.bristol.ac.uk/cmpo/publications/papers/2012/wp284.pdf>. Acesso em: 20 jul. 2020.

MAINWARING, Scott; BRINKS, Daniel; PÉREZ-LIÑAN, Aníbal. Classificando regimes políticos na América Latina, 1945-1999. Dados, v. 44, n. 4, p. 645687, 2001.

MAINWARING, Scott; JONES, Mark P. A nacionalização dos partidos e dos sistemas partidários: uma mediação empírica e sua aplicação ao caso das Américas. In: TAVARES, José Antônio Giusti (Org.). O sistema partidário na consolidação da democracia brasileira. Brasília: Instituto Teotônio Vilela, 2003, p. 101-148.

MAINWARING, Scott; SCULLY, Timothy (Ed.). Building democratic institutions: party systems in Latin America. Stanford: Stanford University Press, 1995.

MAINWARING, Scott; SHUGART, Matthew Soberg (Ed.). Presidentialism and democracy in Latin America. Cambridge: Cambridge University Press, 1997.

MAINWARING, Scott; TORCAL, Mariano. Teoria e institucionalização dos sistemas partidários após a terceira onda de democratização. Opinião Pública, v. 9, n. 2, p. 249-286, out. 2005.

MALDONADO: la intendencia entró ayer en la para rechazar crítica a Antía campaña. La Red 21, 11 mayo 2000. Disponivel em: <http://www.lr21.com.uy/politica/ 10533-maldonado-la-intendencia-entroayer-en-la-para-rechazar-criticas-a-antia-campana>. Acesso em: $08 \mathrm{dez}$. 2018.

MANIN, Bernard; PRZEWORSKI, Adam; STOKES, Susan C. Eleições e representação. Lua Nova, n. 67, p. 105-138, 2006.

MARCINIUK, Fernanda L.; BUGARIN, Maurício S. A Influência da reeleição nas políticas fiscais subnacionais. Revista Brasileira de Economia, v. 73, n. 2, p. 181-212, abril-jun. 2019.

MARENCO, André; SERNA, Miguel. Por que carreiras políticas na esquerda e na direita não são iguais? Recrutamento legislativo no Brasil, Chile e Uruguai. Revista Brasileira de Ciências Sociais. v. 22, n. 64, p. 93-113, 2007.

MARTINS, Ricardo Henrique Chaves. Radiografia do Partido da Social Democracia Brasileira no estado do Piauí (PSDB-PI) no período de 1988 a 2010. 2016. Dissertação (Mestrado em Ciência Política). Universidade Federal do Piauí - Teresina. 
A força do cargo: reeleição de chefes do executivo subnacional no Brasil e no Uruguai (2000-2016) | Alvaro Augusto de Borba Barreto

MEDINA, Mercedes. Montevideo y su área metropolitana - estructuración territorial y contexto planificador. Revista Iberoamericana de Urbanismo, ano 8, n. 13, p. 65-88, jun. 2017.

MELONI, Luis Eduardo Negrão. Os efeitos das expectativas de reeleição sobre os ciclos políticos: uma análise empírica a partir da política fiscal dos municipios brasileiros. 2011. Dissertação (Mestrado em Economia). Universidade de São Paulo. São Paulo.

MENDES, Marcos; ROCHA, Carlos Alexandre Amorim. Reeleição sob informação imperfeita: evidência para os municípios brasileiros. Série Texto para discussão. Brasília: Departamento de Economia/UnB, n. 313, jun. 2004.

MENDES, Marcos; ROCHA, Carlos Alexandre Amorim. O que reelege um prefeito? Textos para discussão. Brasília: Senado, n. 4, abr. 2004a. Disponivel em: <http://www2.senado.leg.br/bdsf/item/id/99>. Acesso em: 20 jul. 2020.

MENEGUIN, Fernando B.; BUGARIN, Maurício. 2001. Reeleição e política fiscal: um estudo dos efeitos da reeleição nos gastos públicos. Revista de Economia Aplicada, v. 5, n. 3, p. 601-622, 2001.

MENEGUIN, Fernando B.; BUGARIN, Maurício; CARVALHO, Alexandre X. de. O que leva um governante à reeleição? Textos para discussão. Brasília, IPEA, n. 1135, nov. 2005.

MENEZES, Rafael Terra de; SAIANI, Carlos César Santejo; ZOGHBI, Ana Carolina Pereira. Demanda mediana por serviços públicos e desempenho eleitoral: evidências do modelo do eleitor mediano para os municípios brasileiros. Est. Econ., v. 41, n. 1, p. 25-57, jan.-mar. 2011.

MICARLA de Sousa é afastada da Prefeitura de Natal pela justiça. G1, 31 out. 2012. Disponivel em: <http://g1.globo.com/rn/rio-grande-donorte/noticia/2012/10/micarla-de-sousa-e-afastada-da-prefeitura-de-natalpela-justica.html>. Acesso em: 08 dez. 2018.

MIERES, Pablo. Simultaneidad, separación y vinculación de las instancias electorales. Alternativas de reformas y sus efectos posibles en Uruguay. Revista Central de Sociología, n. 6, p. 49-77, 2011.

MORAES, Juan Andrés. Mayoría automática en el Uruguay: la experiencia de los gobiernos departamentales (1984-1994). Revista Uruguaya de Ciencia Política, v. 10, p. 47-78, 1997-1998.

MOREIRA, Constanza. A Esquerda no Uruguai e no Brasil: cultura política e desenvolvimento partidário. Opinião Pública, v. 6, n. 1, p. 17-54, abr. 2000.

MOREIRA, Constanza. Sistema de partidos, alternancia política e ideología en el Cono Sur. Revista Uruguaya de Ciencia Política, n. 15, p. 31-56, 2006. 
A força do cargo: reeleição de chefes do executivo subnacional no Brasil e no Uruguai (2000-2016) | Alvaro Augusto de Borba Barreto

MOREIRA, Manoel Gehrke Ryff. Are incumbents advantaged? Evidences from Brazilian municipalities using a quasi-experimental approach. In: Advancing Electoral Research Elecdem Final Conference, 2012, Florença. Disponivel em: <https://www.semanticscholar.org/paper/Are-IncumbentsAdvantaged-Evidences-from-Brazilian-

Moreira/e8f981cfc0702c59144ea22b8475d7cd702da4fb>. Acesso em: 20 jul. 2020.

NAKAGUMA, Marcos Yamada; BENDER, Siegfried. A emenda da reeleição e a Lei de Responsabilidade Fiscal: impactos sobre ciclos políticos e performance fiscal dos Estados (1986-2002). Economia Aplicada, v. 10, n. 3, p. 377-397, jul.-set. 2006.

NASCIMENTO renuncia à prefeitura de Manaus. Folha de São Paulo, 12 mar. 2004. Disponivel em: $<$ https://www1.folha.uol.com.br/fsp/brasil/fc1203200415.htm>. Acesso em: 08 dez. 2018.

NEVES, Gleisi Heisler. O município no Brasil: marco de referência e principais desafios. Cadernos Adenauer, n. 4, p. 9-33, 2000.

NIS, Ana Laura. Lavalleja y más Partido Nacional. In: CARDARELLO, Antonio; FREIGEDO, Martin (Coord.). El desafio de un cambio - elecciones departamentales y municipales de 2015. Montevideo: Instituto de Ciencia Politica; Congreso de Intendentes, 2017, p. 446-474.

NIS, Ana Laura; GRANJA, Lorena. Lavalleja - El Partido Nacional entre la continuidad y la reinvención. Elecciones departamentales y municipales 2010. In: CARDARELLO, Antonio; MAGRI, Altaïr (Coord.). Cambios, certezas e incertidumbres - elecciones departamentales y municipales de 2010. Montevideo: Instituto de Ciencia Politica; Congreso de Intendentes, 2011, p. 387-407.

NOHLEN, Dieter. La reelección. In: NOHLEN, Dieter et al. (Comp.). Tratado de Derecho Electoral comparado de América Latina. Ciudad de México: Fondo de Cultura Económica; Instituto Interamericano de Derechos Humanos; Universidad de Heidelberg; International IDEA; Tribunal Electoral del Poder Judicial de la Federación; Instituto Federal Electoral, 2007, p. 287293.

NORDHAUS, William D. The political business cycle. Review of Economic Studies, v. 42, n. 2, p. 169-190, 1975.

NOVAES, Lucas Martins. O efeito da reeleição em gastos de saúde - uma análise do modelo de reputação política. 2007. Dissertação (Mestrado em Economia). Fundação Getúlio Vargas. São Paulo.

NOVAES, Lucas; MATTOS, Enlinson. O efeito da intenção de reeleição sobre gastos em saúde: uma análise com base no modelo de reputação política. Revista de Economia Política, v. 30, n. 1 (117), p. 140-158, jan.-mar. 2010. 
A força do cargo: reeleição de chefes do executivo subnacional no Brasil e no Uruguai (2000-2016) | Alvaro Augusto de Borba Barreto

O'DONNELL, Guillermo. Accountability horizontal e as novas poliarquias. Lua Nova. São Paulo, n. 44, p. 27-54, 1998.

OLIVEIRA, Luzia Helena Hermann de. Presidencialismos em perspectiva comparada: Argentina, Brasil e Uruguai. Dados, v. 49, n. 2, p. 301-343, 2006.

OLIVEIRA, Maria Augusta Teixeira. A accountability é bela: punição eleitoral e contas irregulares nas eleições para prefeito entre 2004-2016. 2017. Dissertação (Mestrado em Ciência Política). Universidade Federal de Pernambuco. Recife.

PENFOLD, Michael; CORRALES, Javier; HERNÁNDEZ, Gonzalo. Los invencibles: la reelección presidencial y los cambios constitucionales en América Latina. Revista de Ciencia Politica, v. 34, n. 3, p. 537-559, 2014.

PERDOMO, Sandra; GARRACINI, Pablo. San José tras la senda de Chiruchi. In: CARDARELLO, Antonio; MAGRI, Altaïr (Coord.). Cambios, certezas e incertidumbres - elecciones departamentales y municipales de 2010. Montevideo: Instituto de Ciencia Política; Congreso de Intendentes, 2011, p. 297-319.

PEREIRA, Carlos; RENNÓ, Lucio. O que é que o reeleito tem? Dinâmicas politico-institucionais locais e nacionais nas eleições de 1998 para a Câmara dos Deputados. Dados, v. 44, n. 2, p. 133-172, 2001.

PEREIRA, Carlos; RENNÓ, Lucio. O que é que o reeleito tem? O retorno: o esboço de uma teoria da reeleição no Brasil. Revista de Economia Política, v. 27, n. 4, p. 664-683, 2007.

PEREIRA, Roger. Beto Richa renuncia e já inicia campanha ao governo do PR. Terra, 30 mar. $2010 . \quad$ Disponivel em: <https://www.terra.com.br/noticias/brasil/politica/beto-richa-renuncia-eja-inicia-campanha-ao-governo-do-

pr,b77a63fc8940b310VgnCLD200000bbcceb0aRCRD.html>. Acesso em: 08 dez. 2018.

PÉREZ-LIÑAN, Aníbal. Las instituciones electorales y su impacto politico: los países del Mercosur en perspectiva comparada. Revista Argentina de Ciencia Politica, n. 7-8, p. 35-54, sept. 2004.

PERMANYER, Pedro. Sin novedades en el pago de Gardel. Contextos y escenarios de la competencia politica 2010 en Tacuarembó. In: CARDARELLO, Antonio; MAGRI, Altaïr (Coord.). Cambios, certezas e incertidumbres - elecciones departamentales y municipales de 2010. Montevideo: Instituto de Ciencia Política; Congreso de Intendentes, 2011, p. 409-431.

PERMANYER, Pedro. Evolución del sistema de partidos e influencia del régimen electoral - Tacuarembó, 1984-2005. 2009. Monografia (Licenciatura em Ciência Política). Universidad de la República - Montevideo. 
PERMANYER, Pedro; STUHLDREHER, Amalia. Elecciones departamentales y municipales de 2015 en Tacuarembó. Cambios y continuidades en las tendencias electorales. In: CARDARELLO, Antonio; FREIGEDO, Martin (Coord.). El desafio de un cambio - elecciones departamentales y municipales de 2015. Montevideo: Instituto de Ciencia Política; Congreso de Intendentes, 2017, p. 475-502.

POSE, Nicolás. De actor de reparto a protagonista: análisis de las elecciones departamentales en Uruguay (1984-2010). XII Jornadas de Investigación de la Facultad de Ciencias Sociales, Udelar. Montevideo, 16-18 set. 2013. Disponivel em: $<$ http://www.academia.edu/5315780/De_actor_de_reparto_a_protagonista_ An\%C3\%A1lisis_de_las_elecciones_departamentales_en_Uruguay_19842010_>. Acesso em: 08 dez. 2018.

PREFEITO do Rio Branco quer vaga na Câmara Federal. Diário do Grande ABC, 13 set. $2000 . \quad$ Disponivel em: $<$ http://www.dgabc.com.br/Noticia/447873/prefeito-do-rio-branco-quervaga-na-camara-federal?referencia=buscas-lista>. Acesso em: 18 dez. 2018.

PREFEITO DE PORTO Velho é afastado do cargo e proibido de entrar na prefeitura. G1, 06 dez. 2012. Disponivel em <http://g1.globo.com/ro/rondonia/noticia/2012/12/prefeito-de-portovelho-e-afastado-do-cargo-e-proibido-de-entrar-na-prefeitura.html>. Acesso em: 08 dez. 2018.

PSB ANUNCIA que prefeito de Cuiabá não vai concorrer à reeleição. G1, 04 ago. 2016. Disponivel em: <http://g1.globo.com/matogrosso/noticia/2016/08/psb-anuncia-que-prefeito-de-cuiaba-nao-vaiconcorrer-reeleicao.html>. Acesso em: 08 dez. 2018.

QUEIROLO, Rosario; BOIDI, Maria Fernanda; CASO, Álvaro. Elecciones internas en Uruguay: un caso de incentivos diferenciados para la movilización electoral. In: MIERES, Pablo (Org.). La campaña electoral 2014 en Uruguay: evolución del voto y del sistema de partidos. Montevideo: Universidad Católica del Uruguay; Fundación Konrad Adenauer, 2015, p. 59-82.

REIS, Guilherme Simões. Ainda a social-democracia? Rediscutindo e aplicando o conceito a partidos competitivos da América do Sul e da Europa. 2013. 302 f. Tese (Doutorado em Ciência Política) - Universidade do Estado do Rio de Janeiro, Rio de Janeiro, 2013.

RIBEIRO FILHO, Antônio Daniel. Os efeitos do periodo de transição governamental nas contas públicas: uma análise em municípios, estados e União. 2011. Dissertação (Mestrado Multi-institucional e Inter-regional de Ciências Contábeis). Universidade de Brasília. Brasília. Universidade Federal da Paraíba. João Pessoa. Universidade Federal do Rio Grande do Norte. Natal. 
A força do cargo: reeleição de chefes do executivo subnacional no Brasil e no Uruguai (2000-2016) | Alvaro Augusto de Borba Barreto

RICARDO Ehrlich. El Observador, 11 abr. 2011. Disponivel em: <https://www.elobservador.com.uy/nota/ricardo-ehrlich-20114111940>.

Acesso em: 08 dez. 2018.

ROGOFF, Kenneth; SIBERT, Anne. Elections and macroeconomic policy cycles. The Review of Economic Studies, v. 55, n. 1, p. 1-16, jan. 1988.

RUBEN Rodríguez no se presenta a la reelección. La Red 21, 11 feb. 2000. Disponivel em: <http: / /www.1r21.com.uy/politica/2709-ruben-rodriguez-nose-presenta-a-la-reeleccion>. Acesso em: 08 dez. 2018.

SAKURAI, Sérgio Naruhiko. Ciclos eleitorais, reeleição e déficit fiscal nos municípios brasileiros: uma análise via dados em painel. 2007. Tese (Doutorado em Teoria Econômica). Universidade de São Paulo. São Paulo.

SAKURAI, Sérgio Naruhiko; MENEZES FILHO, Naércio Aquino. Fiscal policy and reelection in Brazilian municipalities. Public Choice, v. 137, n. 1-2, p. 301-314, oct. 2008.

SALVAT, Richard. Carreras politicas en la Junta Departamental de Florida: inestabilidad y amateurismo. 1985-2005. 2006. Monografia (Licenciatura em Ciência Política). Universidad de la República - Montevideo.

SANTANA, Luciana. Perfil, trajetórias e ambição politica dos legisladores na construção de suas carreiras: Argentina, Brasil, Chile e Uruguai. Teoria \& Sociedade, v.16, n.2, p.130-155, jul.-dez. 2008.

SANTOS, André Marenco dos. Quando comparamos para explicar desenhos de pesquisa e sequências temporais na investigação de instituições políticas. Revista Brasileira de Ciências Sociais, v. 27, n. 80, p. 203-217, out. 2012.

SARTORI, Giovanni. Engenharia constitucional. Brasilia: UnB, 1996.

SCARANO, Bruno Caminha. Os gastos públicos com pessoal e sua relação com a proximidade das eleições - uma análise empírica para os municipios cearenses no período de 2009 a 2016. 2018. Dissertação (Mestrado Profissional em Economia do Setor Público). Universidade Federal do Ceará. Fortaleza.

SEABRA, Catia. Serra deixa prefeitura após 15 meses para disputar governo. Folha de São Paulo, 01 abr. 2006. Disponivel em: <https://www1.folha.uol.com.br/fsp/brasil/fc0104200602.htm>. Acesso em: 08 dez. 2018.

SERNA, Miguel. Reconversão democrática das esquerdas no Cone Sul. Bauru: Edusc, 2004.

SERRAFERO, Mario D. Reelección presidencial, ventajas del candidato e inequidad electoral. Anales de la Academia Nacional de Ciencias Morales y Politicas. 2016, p. 3-24. Disponivel em: 
A força do cargo: reeleição de chefes do executivo subnacional no Brasil e no Uruguai (2000-2016) | Alvaro Augusto de Borba Barreto

<https://www.ancmyp.org.ar/user/files/Serrafero.I.16.pdf>. Acesso em: 20 jul. 2020.

SERRAFERO, Mario D. La reelección presidencial indefinida en América Latina. Revista de Instituciones, Ideas y Mercados, n. 54, p. 225-259, mayo 2011.

SERRAFERO, Mario D. Reelección presidencial en América Latina: evolución y situación actual. Anales de la Academia Nacional de Ciencias Morales y Políticas. 2010, p. 5-30. Disponivel em: $<$ https://www.ancmyp.org.ar/user/files/05-Serrafero.pdf>. Acesso em: 20 jul. 2020.

SERRAFERO, Mario D. Reelección y sucesión presidencial. Poder y continuidad - Argentina, América Latina y EE. UU. Buenos Aires: Belgrano, 1997.

SHIKIDA, Cláudio Djissey et al. "It is the economy, companheiro!": an empirical analysis of Lula's re-election based on municipal data. Economics Bulletin, v. 29, p. 976-991, 2009.

SHUGART, Matthew; CAREY, John. Presidents and assemblies. Constitutional design and electoral dynamics. Cambridge: Cambridge University Press, 1992.

SILVA, Fabrício Pereira da. Vitórias na crise: trajetórias das esquerdas latino-americanas contemporâneas. Rio de Janeiro: Ponteio, 2011.

SILVA, Sibele Leandra Penna; FARONI, Walber; BARBIÉRI, Roberto Santos. Ciclos político-orçamentários e reeleição: um estudo para os municípios do Norte do Brasil. Revista Científica da Faminas, v. 7, n. 1, p. 99-120, 2011.

SILVIO Mendes confirma renúncia em entrevista na TV Cidade Verde. CidadeVerde.com, 29 mar. 2010. Disponivel em: $<$ https://cidadeverde.com/noticias/55626/silvio-mendes-confirmarenuncia-em-entrevista-na-tv-cidade-verde>. Acesso em: 08 dez. 2018.

SOLO 4 intendentes no se presentan a reelección. Montevideo Portal, 21 dic. 2009. Disponivel em: <https://www.montevideo.com.uy/Noticias/Solo-4intendentes-no-se-presentan-a-reeleccion-uc99061>. Acesso em: $08 \mathrm{dez}$. 2018.

SOUZA, Carlos Alberto de; GERCHMANN, Léo. Genro atribui escolha à aproximação de facções. Folha de São Paulo, 11 abr. 2000. Disponível em: <http://www1.folha.uol.com.br/fsp/brasil/fc1104200023.htm>. Acesso em: 08 dez. 2018.

SUÁREZ-CAO, Julieta; FREIDENBERG, Flavia. Sistemas de partido multinivel y democracia: nueva tipología de partidos y sistemas de partidos en América Latina. In: FREIDENBERG, Flavia; SUÁREZ-CAO, Julieta (Org.). Territorio y poder: nuevos actores y competencia política en los sistemas de partidos multinivel en América Latina. Salamanca: Universidad de Salamanca, 2014, p. 11-44. 
A força do cargo: reeleição de chefes do executivo subnacional no Brasil e no Uruguai (2000-2016) | Alvaro Augusto de Borba Barreto

THOMPSON, José. La reelección y sus implicaciones para la equidad en la contienda electoral. Cuadernos de Capel, n. 57, p. 279-288, sep. 2012.

TITIUNIK, Rocío. Incumbency advantage in Brazil: evidence from municipal mayor elections. Berkeley, CA: Center for Political Studies, Institute for Social Research, University of Michigan, april 2011. Disponivel em: <https:/ / www.semanticscholar.org/paper/Incumbency-Advantage-in-Brazil$\% 3 \mathrm{~A}-$ Evidence-from-\%E2\%88\%97-

Titiunik/40d5942551621af6370158fe3b4ef278520e0a8e>. Acesso em: 20 jul. 2020.

TOLEDO, José Roberto de. 73\% reprovam governo Pitta e 60 querem seu impeachment. Folha de São Paulo, 20 jul. 2000. Disponivel em: <www1.folha.uol.com.br/fsp/cotidian/ff09049901.htm>. Acesso em: 08 dez. 2018.

TORCAL, Mariano (Coord.). Sistemas de partidos en América Latina: causas y consecuencias de su equilibrio inestable. Barcelona; Santa Fe, Arg.: Anthropos; Universidad Nacional del Litoral, 2015.

TRAVERSA, Federico. Elecciones municipales de mayo de 2000: una perspectiva de análisis para interpretar los resultados y el caso particular del departamento de Colonia. In: LAURNAGA, Maria Elena (Coord.). La geografia de un cambio. Política, gobierno y gestión municipal en Uruguay. Montevideo: Banda Oriental, 2001, p. 63-73.

TRIGUEIRO, Dayana. Fim de papo: Agra rompe com Ricardo, descarta Estela e avisa que vai participar da campanha de outro palanque. Jun. 2012. Disponivel em: <http://dayanapb.blogspot.com.br/2012/06/fim-de-papoagra-rompe-com-ricardo.html>. Acesso em: 08 dez. 2018.

UMENO, Luis Gustavo; BUGARIN, Mauricio Soares. Electoral control in the presence of moral hazard and adverse selection. Brazilian Review of Econometrics, v. 28, n. 1, p.17-50, 2008.

UOL. Raio X. Eleições 2016. 2016. Disponivel em: <https: / /www.uol/eleicoes / especiais / raio-x-2016-1-turno.htm\#raio-xeleicoes-2016>. Acesso em: 08 dez. 2018.

URUGUAY. Constitución de la República. 2018. Disponivel: $<$ https://parlamento.gub.uy/documentosyleyes/constitucion>. Acesso em: 08 dez. 2018.

URUGUAY. CORTE ELECTORAL. Estadísticas. 2018. Disponível em: <http:/ / www.corteelectoral.gub.uy/gxpsites / page.aspx?3,26,294,O,S,0,>. Acesso em: 08 dez. 2018.

URUGUAY. INE (INSTITUTO NACIONAL DE ESTADÍSTICA). Censos 2011. 2018. Disponivel em: <http://www.ine.gub.uy/censos-2011>. Acesso em: 08 dez. 2018. 
A força do cargo: reeleição de chefes do executivo subnacional no Brasil e no Uruguai (2000-2016) | Alvaro Augusto de Borba Barreto

URUGUAY. INE. Anuário Estadístico 2017. Montevideo: INE, 2017. Disponivel em: <http://www.ine.gub.uy/documents/10181/496405/Anuario+2017.pdf/ea 4a21e5-2b2a-41b1-99d2-9312cd97700a>. Acesso em: 08 dez. 2018.

URUGUAY. INE. Toponimia y categorización jurídica oficial de las localidades urbanas de Uruguay. Montevideo, 2010. Disponível em: <http:/ /www.ine.gub.uy/documents / 10181/34551/Toponimia+y+categoriza ci\%C3\%B3n+jur\%C3\%ADdica+oficial+de+las+localidades+urbanas+de+Urug uay/f1af89b9-6d5c-42bc-9826-ec5cbe6b4ffd>. Acesso em: 08 dez. 2008.

URUGUAY. PODER LEGISLATIVO. Ley 17.717. 2018. Disponivel em: <https://legislativo.parlamento.gub.uy/temporales/leytemp5825911.htm>. Acesso em: 08 dez. 2018.

VAIRO, Daniela. "Juntos pero no casados": los efectos de la reforma constitucional al interior de los partidos. Revista Uruguaya de Ciencia Política, v. 17, n. 1, p. 159-181, enero-dic. 2008.

VAIRO, Daniela; PEREYRA, José. Del resultado incierto a la victoria contundente. Un examen de las elecciones departamentales y municipales 2010 en Maldonado. In: CARDARELLO, Antonio; MAGRI, Altaïr (Coord.). Cambios, certezas e incertidumbres - elecciones departamentales y municipales de 2010. Montevideo: Instituto de Ciencia Política; Congreso de Intendentes, 2011, p. 85-108.

VASQUEZ, Vitor Lacerda. Ao vencedor, a prefeitura: competição em eleições municipais (1996-2012). 2016. Dissertação (Mestrado em Ciência Política). Universidade Estadual de Campinas. Campinas.

WILSON Santos renuncia amanhã e Chico Galindo assume na quinta. Olhar Direto, $30 \quad$ mar. $2010 . \quad$ Disponivel em: <http://www.olhardireto.com.br/noticias / exibir.asp?id=92946\&noticia=wils on-santos-renuncia-amanha-e-chico-galindo-assume-na-quinta>. Acesso em: 08 dez. 2018.

XAVIER, Juan Francisco. El voto: ¿el doble rostro de Jano? El proceso electoral 2004/2010 en Rivera: una aproximación desde la Sociología y la Ciencia Política. Montevideo: Carlos Alvarez, 2013. 